\title{
Dental Implants Inserted in Fresh Extraction Sockets versus Healed Sites: A Systematic Review and Meta-Analysis
}

\author{
Adam Ibrahim ${ }^{1}$ and Bruno Ramos Chrcanovic ${ }^{2, *(D)}$ \\ 1 Faculty of Odontology, Malmö University, 21421 Malmö, Sweden; adamib.1995@gmail.com \\ 2 Department of Prosthodontics, Faculty of Odontology, Malmö University, 21421 Malmö, Sweden \\ * Correspondence: bruno.chrcanovic@mau.se
}

Citation: Ibrahim, A.; Chrcanovic, B.R. Dental Implants Inserted in Fresh Extraction Sockets versus Healed Sites: A Systematic Review and Meta-Analysis. Materials 2021, 14, 7903. https://doi.org/10.3390/ ma14247903

Academic Editors: Paolo Cappare and Antoniac Iulian

Received: 11 November 2021 Accepted: 17 December 2021 Published: 20 December 2021

Publisher's Note: MDPI stays neutral with regard to jurisdictional claims in published maps and institutional affiliations.

Copyright: (c) 2021 by the authors. Licensee MDPI, Basel, Switzerland. This article is an open access article distributed under the terms and conditions of the Creative Commons Attribution (CC BY) license (https:// creativecommons.org/licenses/by/ $4.0 /)$.

\begin{abstract}
The present review aimed to evaluate the difference of dental implant failure rates and marginal bone loss (MBL) between implants inserted in fresh extraction sockets or healed sites. Electronic search was undertaken in three databases, plus manual search of journals, including studies randomized or not. Meta-analyses were performed besides meta-regressions, in order to verify how the odds ratio (OR) and MBL were associated with follow-up time. The review included 163 publications. Altogether, there were 17,278 and 38,738 implants placed in fresh extraction sockets and healed sites, respectively. Pairwise meta-analyses showed that implants in sockets had a higher failure risk in comparison to healed sites: OR 1.349, all studies included; OR 2.070, only prospective non-RCTs; OR 2.487, only RCTs (all $p<0.001$ ). The difference in implant failure between the groups was statistically significant in the maxilla (OR 1.616, $p=0.029$ ), but not in the mandible (OR 2.192, $p=0.075)$. The MBL mean difference (MD) between the groups was $-0.053 \mathrm{~mm}(p=0.089)$. There was an estimated decrease of 0.003 in OR $(p=0.284)$ and an increase of $0.006 \mathrm{~mm}(p=0.036)$ in the MBL MD between groups for every additional month of follow-up. In conclusion, implants placed in fresh extraction sockets present higher risk of failure than implants placed in healed sites.
\end{abstract}

Keywords: dental implant; failure; marginal bone loss; fresh extraction socket; healed site; systematic review; meta-analysis; meta-regression

\section{Introduction}

According to the first installation protocol for the modern dental implant, it was recommended that the implant should be surgically placed only after a period of healing of the alveolar socket after tooth extraction, so adequate remodeling and healing of the alveolar bone would occur in order to optimize osseointegration of the implant [1]. The placement of implants in the alveolar socket right after tooth extraction was established as a new surgical protocol [2]. The procedure aimed to reduce treatment time, to decrease the number of surgical sessions, to minimize the post-extraction resorption of the alveolar bone, to provide a positive psychological impact on the patient, and to have the ability to place the implant in an ideal axial position in relation to the tooth that once occupied the socket [3]. The immediate placement of implants has even been advocated into infected sites [4]. However, the technique is not without drawbacks, as the alveolar socket may present reduced amount of bone in order to provide implant primary stability [5]. Therefore, the approach is potentially risky.

The possible negative effect of the insertion of implants in fresh extraction sockets has raised some concerns about the long-term survival of dental implants installed by this approach. A previous systematic review on the subject had shed some light on the issue [6]. The results suggested that placement of implants in extraction sockets may have an influence on the implant failure rates when compared to installation in healed sites. This review was published several years ago, and since then, many more clinical studies evaluating both techniques have been published. It was therefore the aim of the present 
systematic review to perform an update on the subject, adding more information from additional studies.

\section{Materials and Methods}

This study followed the PRISMA 2020 Statement guidelines [7]. Register in PROSPERO was undertaken with the registration number CRD42021240677.

\subsection{Objective}

The purpose of the present study was to test the null hypothesis of no difference in the implant failure rates and marginal bone loss (MBL) for the insertion of dental implants in fresh extraction sockets compared to the insertion in healed sites, against the alternative hypothesis of a difference, based on a systematic review of the literature. The focused question was elaborated by using the PICO format (participants, interventions, comparisons, outcomes): In patients being rehabilitated with dental implants, what is the effect of placement of implants in fresh extraction sockets on the implant failure rates and MBL in comparison to placement in healed sites?

\subsection{Search Strategies}

An electronic search without time restrictions was undertaken in October 2021 in the following databases: PubMed/Medline, Web of Science, and Science Direct. The following terms were used in the search strategies:

(dental implant OR oral implant) AND ("fresh extraction socket" OR "immediate placement" OR "immediate insertion" OR "immediate implant").

A manual search of dental implant-related journals (listed in the Supplementary Material) was performed. The reference list of the identified studies and the relevant reviews on the subject were also checked for possible additional studies.

\subsection{Inclusion and Exclusion Criteria}

Clinical human studies were included, either randomized or not, with information on implant failure rates in diabetic and in non-diabetic individuals, rehabilitated with cylindrical modern dental implants of commercially pure titanium or its alloys. Case reports, technical reports, animal and in vitro studies, and reviews papers were excluded. Studies evaluating mini-implants, zygomatic, orthodontic, zirconia, subperiosteal, or hollow implants were excluded.

\subsection{Study Selection}

The titles and abstracts of all reports identified through the electronic searches were read independently by the authors. For studies appearing to meet the inclusion criteria, or for which there were insufficient data in the title and abstract to make a clear decision, the full report was obtained. Disagreements were solved by discussion between the authors.

RefWorks Reference Management Software (version 4.6.241, Ex Libris, Jerusalem, Israel) was used in order to detect duplicate references in different electronic databases.

\subsection{Quality Assessment}

Quality assessment of the studies was executed according to the Quality Assessment Tool of the National Institutes of Health [8]. Studies of "good" quality were judged to have at least 7 points.

\subsection{Definitions}

An implant was considered a failure if presenting signs and symptoms that led to implant removal, i.e., a lost implant.

The insertion of an implant into a fresh extraction socket was defined as a dental implant that was placed in the alveolar socket immediately after a tooth was extracted from this socket. It is also called an 'immediate implant' in the literature. 
The insertion of an implant in a healed site was defined as a dental implant that was placed in the site where a tooth was extracted, not immediately after the extraction, but after healing of the extraction socket could occur. This healing period could vary from a couple of weeks to many months, depending on the study.

\subsection{Data Extraction}

The following data were retrieved from the studies: year of publication, study design, country, study setting, number of patients, patients' age and sex, implant healing period, failed and placed implants in each group, MBL, implant system, jaws receiving implants (maxilla and/or mandible), presence of smokers in the patients' study group, and follow-up time. Contact with authors asking for missing data was performed.

\subsection{Analyses}

Implant failure (dichotomous) and MBL (continuous) were the outcomes evaluated. The statistical unit for the outcomes was the implant. The $\mathrm{I}^{2}$ statistic evaluated heterogeneity, and the inverse variance method was used for random-effects or fixed-effects model, depending on the heterogeneity. The estimates of relative effect for implant failure were expressed in odds ratio (OR) and in mean difference (MD) in millimeters for MBL. Meta-regressions were performed to verify how the OR and MBL were associated with the time of follow-up. The data were analyzed using OpenMeta[Analyst] [9]. A funnel plot (plot of effect size versus standard error) was drawn, with the software OpenMEE [10].

\section{Results}

\subsection{Literature Search}

The study selection process is summarized in Figure 1. The search initially resulted in 5648 papers (1626 in Pubmed, 1904 in Web of Science, 2118 in ScienceDirect), of which 163 publications were eligible for inclusion.

\subsection{Description of the Studies}

Table S1 (see Supplementary Material) presents detailed data of the 163 included studies [11-173]. The articles were published between 1994 and 2021. A total of 108 studies were unicenter, 50 were multicenter, and it was not possible to acquire clear information about this for the other five studies. When it comes to study design, 34 studies were randomized clinical trials (RCT), 16 were prospective studies (without a pre-established controlled group), 34 were prospective controlled clinical trials, and 79 were retrospective observational studies. For 68 studies, at least one university was reported as the institution where the study was carried out, which was the case for private dental practice for 100 studies. Multicenter studies could include the two types of institutions, namely private practices and universities. For seven studies it was not possible to acquire information on the type of institution where the study was performed. Italy was the country where the research was carried out for 68 studies (other countries could be included in case of multicenter studies). Other common places for the studies (the same observation for multicenter studies applies here) were the USA in 19 cases, Spain in 14 cases, Germany in 12 cases, Belgium in 11 cases, Brazil in 6 cases, Sweden, France, Austria, and Portugal in 5 cases each, among others. 


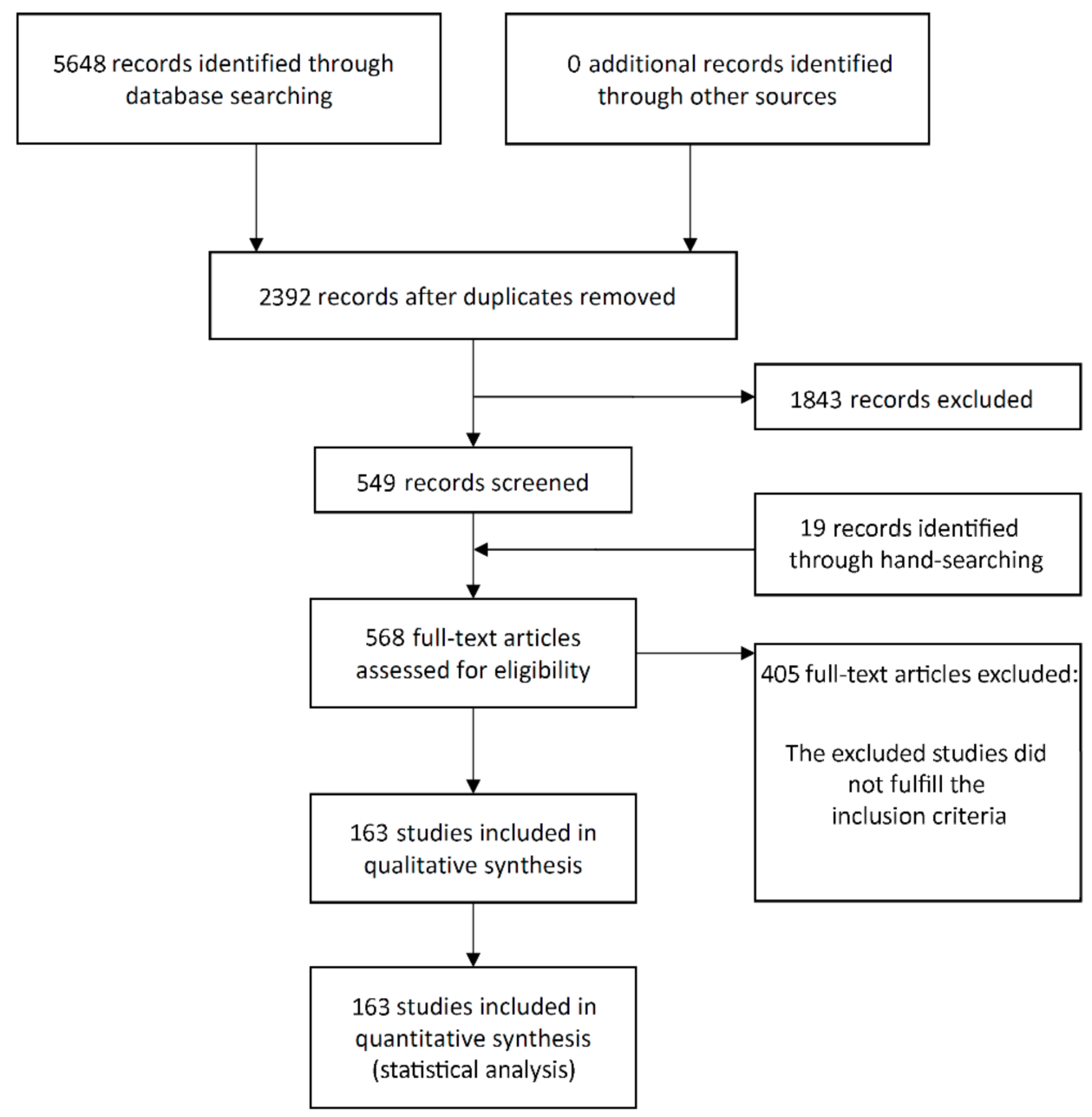

Figure 1. Study screening process.

The mean follow-up \pm standard deviation of 158 studies was $34.2 \pm 26.9$ months (min$\max , 4-124.8$ ). For the other five studies, there was neither information on the precise time of follow-up nor the mean follow-up time. Information on follow-up in these 43 studies was usually reported as, for example, "patients were followed up between the years 2010 to 2012", or "patients were followed up for up to 60 months".

Immediate prosthetic loading of the implants was applied in 106 studies, early loading in 14 studies, and delayed loading in 74 studies. These loading protocols could be either separately (either immediate, or early, or delayed) applied for all implants of a study, or a combination of them for different implants of the same study. For five studies, the implants were not loaded, and for six studies, this information was not available.

Most of the studies $(n=118)$ included implants installed in the maxilla and mandible; 32 studies included patients that received implants only in maxillae, and the other 13 studies included only implants placed in mandibles.

Smokers were excluded from 15 studies. Information on the presence or the absence of smokers among the patients was not available for 30 studies.

Altogether, there were 17,278 implants that were placed in fresh extraction sockets and 38,738 implants placed in healed sites, and 622 and 1113 implant failures in these groups, respectively. Implants most commonly used were from the following manufacturers: Nobel Biocare (Göteborg, Sweden) in 38 studies, Straumann (Basel, Switzerland) in 19 studies, Dentsply (Mannheim, Germany) in 14 studies, and Astra Tech (Mölndal, Sweden) in 13 studies. Information on which implant brand and/or system used was not available in eight studies. 
Mean MBL, separated by the focus groups of the present review, was reported in 46 studies, of which 43 also provided information on standard deviation, necessary to conduct a meta-analysis of continuous variables.

\subsection{Quality Assessment}

All included studies were classified as "good" according to the quality assessment tool (Table S2-see Supplementary Material). In most cases, the main issues in the publications were related to statistical methods not well-described and to the inclusion of non-consecutive patients in the studies.

\subsection{Meta-Analyses}

A random-effects model was used to evaluate the comparison of the implant failure between the two groups, despite the results of the $\mathrm{I}^{2}$ statistic $\left(\tau^{2}=0.000, \mathrm{Chi}^{2}=159.915\right.$, $\mathrm{I}^{2}=0, p=0.532$ ), as it was clearly observed that the 163 included studies presented many clinical and methodological differences. It is more clinically relevant to practitioners to identify potential sources of heterogeneity rather than simply quantify its existence. Examining for potential clinical and methodological differences between studies should be conducted rather than simply relying on tests to report the presence of heterogeneity [174]. It is important to recognize that a non-significant test for heterogeneity does not guarantee homogeneity between all trials included in a meta-analysis [175]. The $\mathrm{I}^{2}$ statistic has actually a relatively low power to demonstrate statistical heterogeneity, and the need to evaluate for clinical and methodological heterogeneity even in the face of little statistical heterogeneity between trials [176].

The pairwise meta-analysis showed implants placed in fresh extraction sockets had a higher risk of failure than implants placed in healed sites, with an OR 1.349 (95\% CI, 1.204, $1.512, p<0.001$; Figure S1—Supplemental Material). An OR of 1.349 implies that implants placed in fresh extraction sockets present a 1.349 higher risk of failures happening than implants placed in healed sites; i.e., fresh extraction socket implants have a higher risk of failure by $34.9 \%$ in relation to healed site implants.

Subgroups analyses were performed for the groups of studies of different designs. The OR for implant failure when only randomized controlled trials (RCT) were pooled was 2.487 (95\% CI, 1.639, 3.772, $p<0.001$; Figure S2-Supplemental Material). The OR for implant failure when only prospective non-RCT were pooled was 2.070 (95\% CI, 1.471, 2.912, $p<0.001$; Figure S3-Supplemental Material).

Subgroups analyses were performed for the group of studies evaluating implants inserted exclusively in different jaws. The OR for implant failure when only studies evaluating implants inserted in maxillae were pooled was 1.616 (95\% CI, 1.049, 2.488, $p=0.029$; Figure 2), and when only studies evaluating implants inserted in mandibles were pooled was 2.192 ( $95 \%$ CI, 0.925, 5.193, $p=0.075$; Figure 3). Thus, the difference in implant failure between the groups was statistically significant in the maxilla, but not in the mandible.

Subgroups analyses were performed for the group of studies evaluating implants inserted exclusively by either immediate or delayed loading protocol. The OR for implant failure when only studies evaluating implants immediately loaded were pooled was 1.785 (95\% CI, 1.361, 2.340, $p<0.001$; Figure 4), and when only studies evaluating implants with delayed loading were pooled was 1.346 (95\% CI, 1.063, 1.705, $p=0.014$; Figure 5). 


\section{Studies}

Agliardi 2014

Arora 2018

Barbier 2012

Cannizzaro (01) 2008

Cooper 2014

Cosyn (2) 2013

De Bruyn (2) 2013

Di Alberti 2012

Esposito (2) 2012

Esposito (3) 2015

Felice (1) 2011

Felice (3) 2015

Gillot (2) 2012

Grandi (1) 2013

Jaffin 2004

Lindeboom 2006

Locante 2004

Malchiodi (1) 2011

Mangano (1) 2013

Mangano (2) 2017

Norton (1) 2004

Ormianer (2) 2012

Palattella 2008

Peñarrocha-Oltra (1) 2012

Peñarrocha-Oltra (2) 2013

Polizzi (2) 2015

Raes (1) 2012

Raes (2) 2013

Raes (3) 2016

Ribeiro 2008

Romanos (3) 2014
Estimate (95\% C.I.)

$0.658(0.031, \quad 13.970$

$1.000(0.019, \quad 53.659)$

$1.000(0.020,51.232)$

$4.406(0.598,32.467)$

$3.288(0.332, \quad 32.609)$

$1.100(0.202, \quad 5.997)$

$3.288(0.332, \quad 32.609)$

$1.784(0.034,92.650)$

$9.353(0.174,502.159)$

$5.000(0.234,106.677)$

$5.000(0.234,106.677)$

$5.426(0.247,118.958)$

$4.640(0.539, \quad 39.927)$

$2.087(0.177,24.615)$

$0.723(0.260,2.011)$

$5.426(0.247,118.958)$

$2.670(0.106,67.403$

$2.250(0.445,11.385)$

$0.822(0.016, \quad 43.474)$

$1.447(0.028,74.359)$

$0.232(0.009,6.224)$

$0.547(0.022, \quad 13.628)$

$1.000(0.018,55.799)$

$0.828(0.159, \quad 4.315)$

$9.895(0.525,186.347)$

$1.364(0.187,9.931)$

$1.128(0.069,18.534)$

$6.290(0.242,163.416)$

$1.128(0.069, \quad 18.534)$

$5.874(0.294,117.464)$

$0.488(0.056,4.232)$

Overall $\left(I^{\wedge} 2=0 \%, P=0.985\right) \quad 1.616 \quad(1.049, \quad 2.488)$

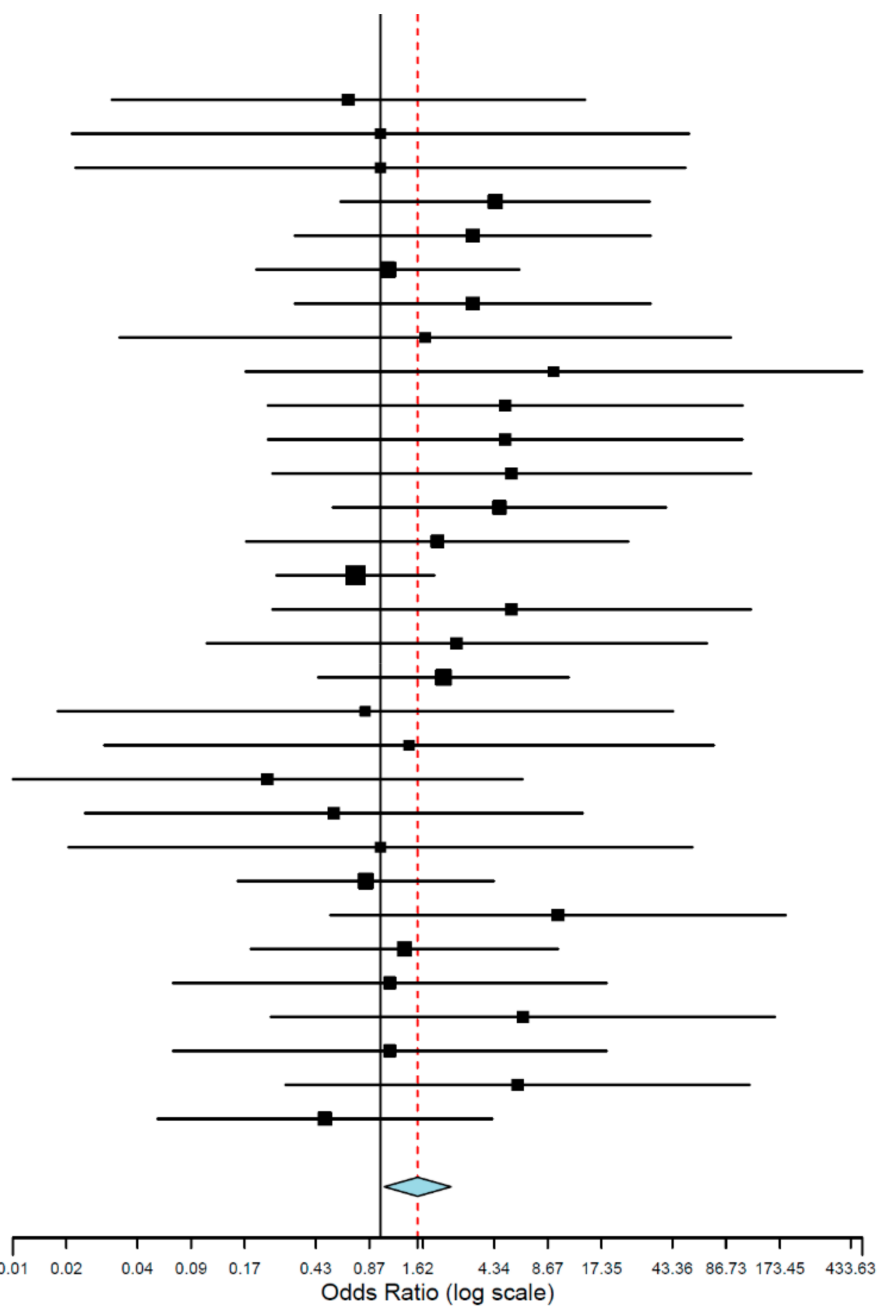

Figure 2. Forest plot for the event 'implant failure', studies evaluating implants inserted exclusively in maxillae. Estimate in Odds Ratio.

Studies

Cannizzaro (10) 2016

Cannizzaro (11) 2017

De Bruyn (1) 2002

Degidi (4) 2007

Gillot (1) 2011

Atieh (1) 2013

Cannizzaro (2) 2008

Krennmair 2014

Leonida 2012

Maló (2) 2003

Wolfinger 2003

Romanos (1) 2012

Swart 2014
Estimate (95\% C.I.)

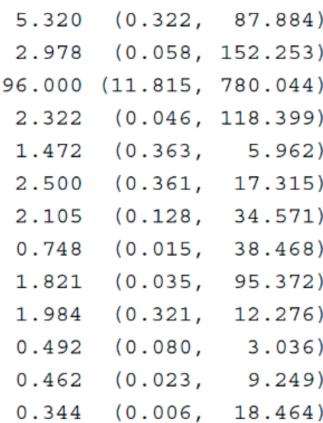

$0.344(0.006,18.464)$

$2.192(0.925, \quad 5.193)$

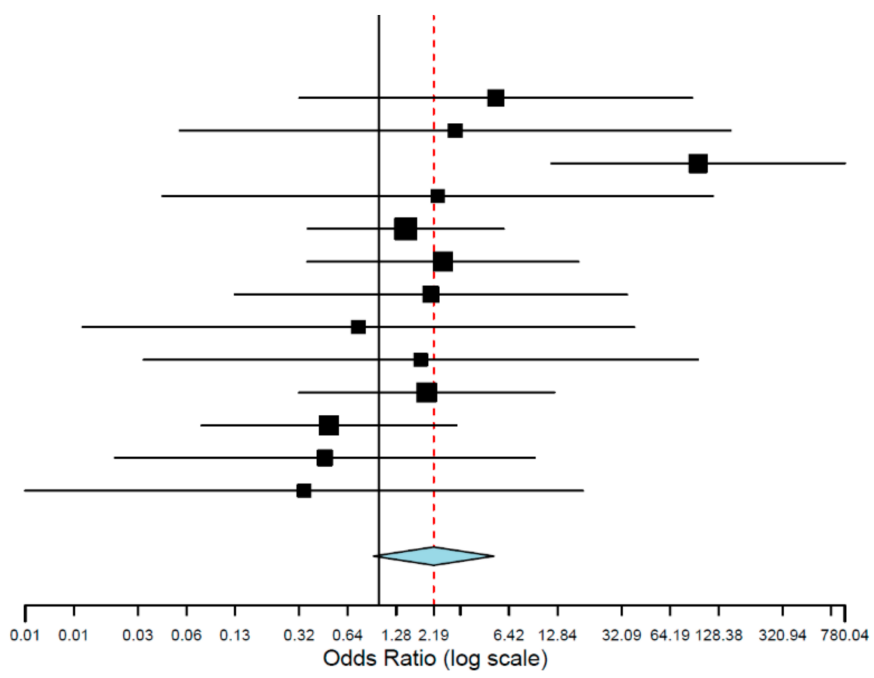

Figure 3. Forest plot for the event 'implant failure', studies evaluating implants inserted exclusively in mandibles. Estimate in Odds Ratio. 
Studies

Polizzi (2) 2015 Agliardi 2014 Agnini 2014

Aguirre-Zorzano 2011 Aires 2002

Amato 2020

Artzi 2010

Atieh (1) 2013

Barbier 2012

Cannizzaro (03) 201

Cannizzaro (05) 2012

Cannizzaro (06) 2015

Cannizzaro (07) 2016

Cannizzaro (08) 2016

Cannizzaro (09) 2016

Cannizzaro (10) 2017

Cannizzaro (11) 2017

Cannizzaro (12) 2018

Chaushu 2001

Ciabattoni 2017

Cooper 2014

Covani 2012

Crespi 2014

De Bruyn (2) 2013

Degidi (1) 2006

Degidi (2) 2007

Degidi (3) 2007

Degidi (4) 2007

Degidi (6) 2015

Deng 2010

Di Alberti 2012

Esposito (3) 2015

Gillot (1) 2011

Gillot (2) 2012

Giordano 2017

Grandi (1) 2013

Jaffin 2004

Ji 2012

Krennmair 2014

Locante 2004

Luongo 2014

Malchiodi (1) 2011

Maló (1) 2000

Maló (2) 2003

Maló (3) 2003

Mangano (1) 2013

Mangano (2) 2017

Noelken 2014

Norton (1) 2004

Norton (2) 2017

Palattella 2008

Pieri 2009

Pozzi (2) 2015

Pozzi (3) 2016

Raes (1) 2012

Raes (2) 2013

Raes (3) 2016

Raes (4) 2018

Ribeiro 2008

Romanos (1) 2012

Romanos (2) 2014

Romanos (3) 2014

Sato 2014

Swart 2014

Thome (2) 2021

Zafiropoulos 2010

Overall ( $\left(\left.\right|^{\wedge} 2=0 \%, P=0.981\right)$
Estimate ( $95 \%$ C.I.)

$1.364(0.187,9.931)$ $0.658(0.031, \quad 13.970)$ $0.178(0.009,3.351)$ $1.216(0.048,30.989)$ $1.607(0.097,26.739)$ $1.503(0.060,37.929)$ $1.382(0.565,3.378)$ $2.500(0.361, \quad 17.315)$ $1.000(0.020,51.232)$ $1.957(0.267,14.337)$ $0.571(0.065,5.015)$ $1.687(0.085,33.645)$ $2.136(0.083,55.171)$ $1.845(0.036,94.980)$ $5.320(0.322 ， 87.884)$ $2.978(0.058,152.253)$ $0.721(0.033,15.588)$ $0.600(0.070,5.150)$ $4.586(0.212,99.196)$ $1.120(0.213,5.886)$ $3.288(0.332, \quad 32.609)$ $0.018(0.001,0.327)$ $3.944(0.188,82.929)$ $3.288(0.332,32.609)$ $7.832(0.422,145.284)$ $5.647(0.496,64.280)$ $1.587(0.395,6.382)$ $2.322(0.046,118.399)$ $2.101(0.514,8.595)$ $16.579(0.862,319.019)$ $1.784(0.034,92.650)$ $5.000(0.234,106.677)$ $1.472(0.363,5.962)$ $4.640(0.539,39.927)$ $3.743(1.113,12.594)$ $2.087(0.177,24.615)$ $0.723(0.260,2.011)$ $3.458(1.268,9.431)$ $0.748(0.015,38.468)$ $2.670(0.106,67.403)$ $1.476(0.056,38.837)$ $2.250(0.445,11.385)$ $5.851(1.341,498.482)$ $1.984(0.321,12.276)$ $0.362(0.019,6.784)$ $0.822(0.016,43.474)$ $1.447(0.028,74.359)$ $1.537(0.057,41.078)$ $0.232(0.009,6.224)$ $3.133(0.057,171.963)$ $1.000(0.018,55.799)$ $1.448(0.089,23.625)$ $7.581(0.356,161.492)$ $3.677(0.147,91.741)$ $1.128(0.069,18.534)$ $6.290(0.242,163.416)$ $1.128(0.069,18.534)$ $1.476(0.056,38.837)$ $5.874(0.294,117.464)$ $0.462(0.023,9.249)$ $6.281(0.987,39.970)$ $0.488(0.056,4.232)$ $3.585(0.069,186.278)$ $0.344(0.006,18.464)$ $0.606(0.025,14.969)$ $3.031(0.641,14.334)$ $1.785(1.361,2.340)$

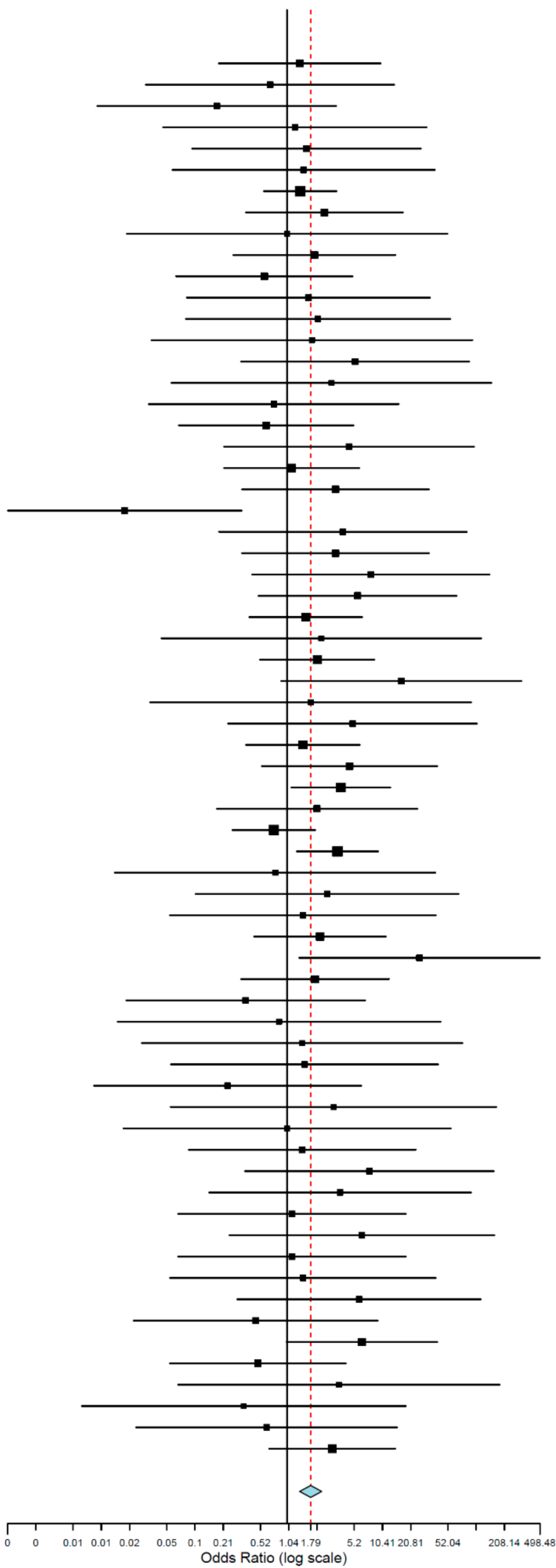

Odds Ratio (log scale)

Figure 4. Forest plot for the event 'implant failure', studies evaluating implants immediately loaded exclusively. Estimate in Odds Ratio. 
Studies

Annibali 2011

Arora 2018

Bae 2011

Cakarer 2014

Callan 2000

Cannata 2017

Cavallaro 2011

Checchi 2017

Dayarpanah 2005

Degasperi 2014

Esposito (4) 2017

Evian 2004

Felice (4) 2016

Gelb 2013

Gomez-Roman 1997

Haas 1996

Horwitz 2007

Huynh-Ba 2019

Kim 2017

Lee (2) 2020

Lindeboom 2006

Malchiodi (2) 2016

Mensdorff-Pouilly 1994

Moraes 2013

Oliva 2012

Pellicer-Chover 2014

Perry 2004

Pettersson 2015

Peñarrocha-Diago (1) 2008

Peñarrocha-Diago (2) 2011

Peñarrocha-Diago (3) 2012

Peñarrocha-Oltra (1) 2012

Polizzi (1) 2000

Prati (1) 2020

Prati (2) 2020

Siciliano 2009

Siebers 2010

Tallarico (2) 2017

Tonetti 2017

Watzek 1995
Estimate (95\% C.I.)

$1.634(0.031,85.575)$

$1.000(0.019,53.659)$

$0.673(0.027,17.085)$

$0.284(0.017,4.782)$

$2.696(0.970,7.497)$

$4.943(0.198,123.577)$

$6.481(0.394,106.722)$

$2.500(0.459, \quad 13.612)$

$3.646(0.370,35.892)$

$26.143(1.000,683.533)$

$1.636(0.425,6.295)$

$1.059(0.401,2.794)$

$2.235(0.364,13.720)$

$1.880(0.037,96.657)$

$0.297(0.039,2.261)$

$1.806(0.808,4.038)$

$4.688(0.948,23.166)$

$0.756(0.014,40.264)$

$0.571(0.023,14.177)$

$1.000(0.018,55.267)$

$5.426(0.247,118.958)$

$1.000(0.019,52.849)$

$1.498 \quad(0.458,4.897)$

$0.837(0.016,44.051)$

$0.718(0.014,37.175)$

$1.058(0.021,54.086)$

$1.097(0.707,1.702)$

$2.952(0.117,74.227)$

$0.432(0.023,8.239)$

$0.680(0.167,2.776)$

$1.192(0.647,2.195)$

$0.828(0.159,4.315)$

$1.011(0.279, \quad 3.670)$

$0.837(0.039,17.992)$

$3.061(0.058,160.412)$

$1.000(0.019,53.659)$

$12.074(1.321,110.374)$

$1.000(0.018,54.465)$

$3.000(0.120,75.191)$

$0.182(0.016,2.074)$

Overall $\left(I^{\wedge} 2=0 \%, P=0.936\right)$

$1.346(1.063,1.705)$

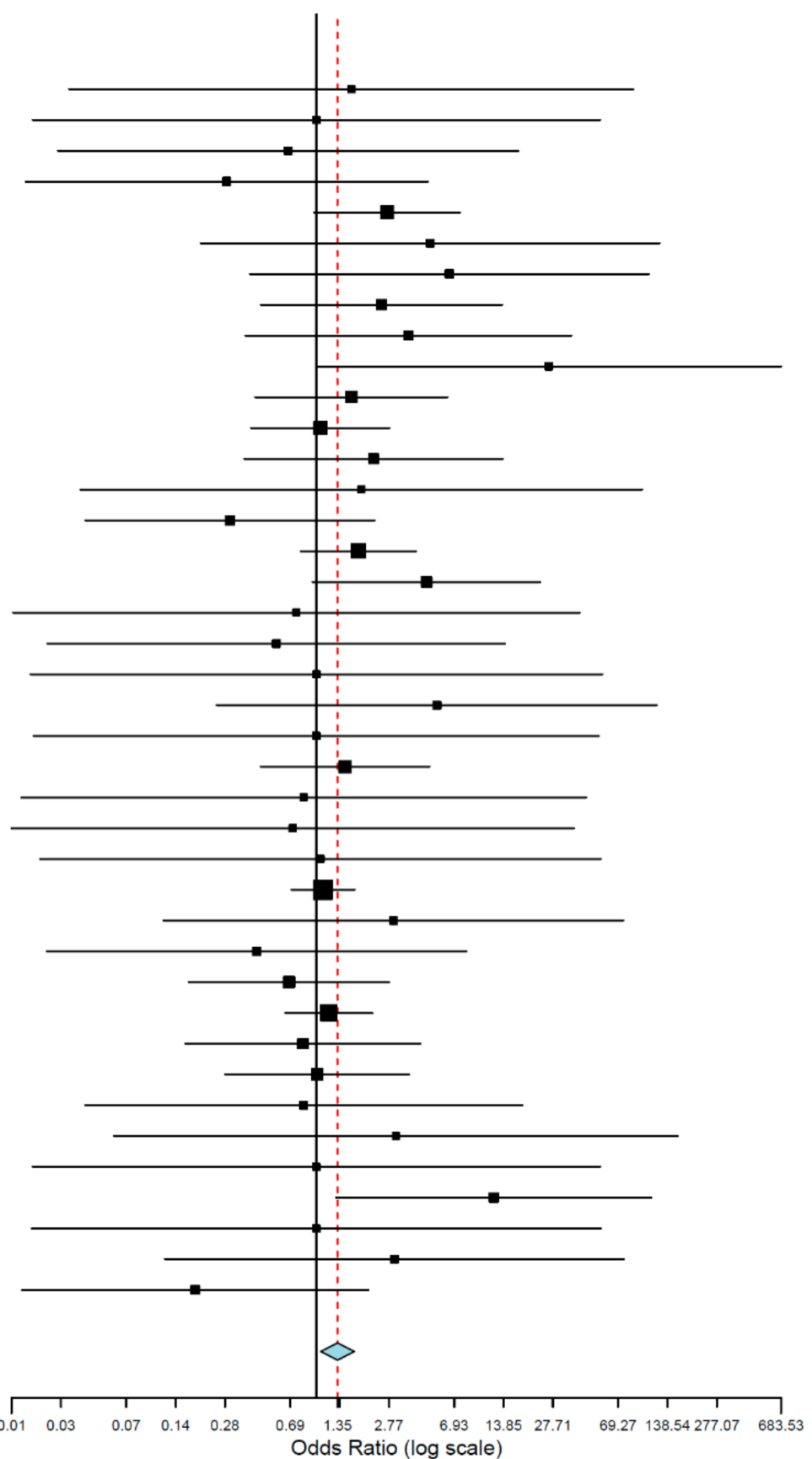

Figure 5. Forest plot for the event 'implant failure', studies evaluating implants with delayed loading exclusively. Estimate in Odds Ratio.

The MD of MBL between the groups was $-0.053 \mathrm{~mm}(95 \% \mathrm{CI},-0.113,0.008$, standard error 0.031, $p=0.089$; Figure 6) $\left(\tau^{2}=0.028, \mathrm{Chi}^{2}=353.522, \mathrm{I}^{2}=87.837, p<0.001\right)$, meaning that implants placed in fresh extraction sockets presented a mean $0.053 \mathrm{~mm}$ higher MBL than the implants placed in healed sites. However, the difference was not statistically significant. 
Studies

Annibali 2011

Arora (mesial) 2018

Artzi 2010

Atieh 2013

Bae 2011

Ciabattoni 2017

Cooper 2014

Cosyn 2013

De Bruyn 2013

Degidi (1) 2007

Degidi (2) 2015

Deng 2010

Esposito (1) 2015

Esposito (2) 2017

Felice 2015

Grandi 2013

Huynh-Ba (mesial) 2019

Kim 2017

Krennmair 2014

Lindeboom (mesial) 2006

Luongo 2014

Malchiodi 2016

Mensdorff-Pouilly 1994

Noelken 2014

Norton 2017

Oxby 2015

Palattella 2008

Pellice-Chover 2014

Peñarrocha-Diago 2011

Peñarrocha-Oltra 2012

Peñarrocha-Oltra (immediate) 2013

Peñarrocha-Oltra (delayed) 2013

Pieri 2009

Polizzi 2015

Pozzi 2016

Prati (1) 2020

Prati (2) 2020

Raes (1) 2013

Raes (2) 2018

Rodrigo (mesial) 2012

Romanos (mesial) 2014

Saridakis 2018

Tallarico (1) 2016

Tallarico (2) 2017

Overall $\left(I^{\wedge} 2=87.84 \%, P<0.001\right)$
Mean Difference (95\% CI)

$0.090(-0.092,0.272)$

$-0.040(-0.256,0.176)$

$-0.310(-0.491,-0.129)$

$-0.450(-0.937,0.037)$

$0.030(-0.525,0.585)$

$-0.570(-0.672,-0.468)$

$-1.960(-2.744,-1.176)$

$0.180(-0.104,0.464)$

$-2.000(-2.760,-1.240)$

$0.100(-0.196,0.396)$

$-0.040(-0.123,0.043)$

$-0.230(-0.354,-0.106)$

$-0.140(-0.199,-0.081)$

$-0.060(-0.118,-0.002)$

$0.060 \quad(0.005,0.115)$

$0.110 \quad(0.003,0.217)$

$0.040(-0.125,0.205)$

$-0.030(-0.112,0.052)$

$-0.320(-0.600,-0.040)$

$-0.030(-0.107,0.047)$

$-0.130(-0.275,0.015)$

$0.280 \quad(0.060,0.500)$

$0.150(-0.124,0.424)$

$0.510(-0.057,1.077)$

$-0.120(-0.285,0.045)$

$0.600 \quad(0.229,0.971)$

$0.080(-0.405,0.565)$

$-0.120(-0.229,-0.011)$

$0.050(-0.004,0.104)$

$-0.110(-0.192,-0.028)$

$0.200 \quad(0.090,0.310)$

$0.100(-0.005,0.205)$

$0.100 \quad(0.021,0.179)$

$-0.690(-1.351,-0.029)$

$0.070(-0.312,0.452)$

$-0.460(-0.735,-0.185)$

$-0.260(-0.517,-0.003)$

$1.230(0.217,2.243)$

$-0.070(-0.208,0.068)$

$0.100(-0.352,0.552)$

$-0.170(-0.661,0.321)$

$-0.060(-0.287,0.167)$

$-0.240(-0.344,-0.136)$

$0.400 \quad(0.214,0.586)$

$-0.053(-0.113,0.008)$
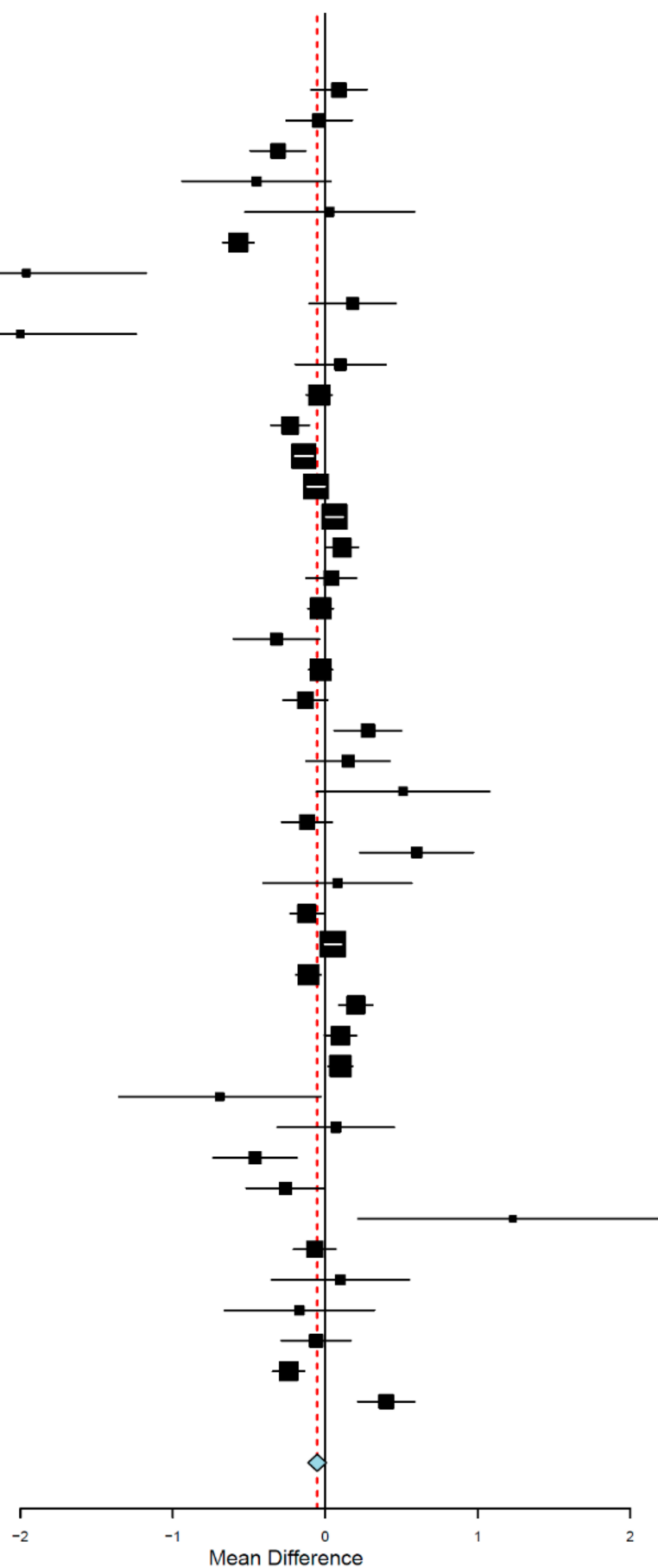

Figure 6. Forest plot for the event 'marginal bone loss'.

\subsection{Meta-Regressions}

A number of 158 studies provided clear information about the follow-up time or mean follow-up time. For the other five studies, no precise follow-up time was possible to be obtained. These studies conducted survival analysis, either life-table or Kaplan-Meier analysis, but with no mean follow-up time provided.

When a meta-regression considering the follow-up period as a covariate in relation to OR was plotted for these 158 studies, it was observed that the follow-up time did not have any effect of the OR of implant failure between the groups. The first-degree equation resulted from the linear regression of this meta-regression was 
$\mathrm{y}=0.589-0.003 \mathrm{x}$, where:

Intercept $=0.589(0.335,0.843)$, standard error $0.130, p<0.001$

Follow-up $=-0.003(-0.009,0.003)$, standard error $0.003, p=0.284$

A sensitivity analysis of the meta-regression was performed plotting together only the studies with follow-up up until 5 years. The first-degree equation resulting from the linear regression of this sensitivity analysis was

$\mathrm{y}=0.702-0.008 \mathrm{x}$, where:

Intercept $=0.702(0.377,1.028)$, standard error $0.166, p<0.001$

Follow-up $=-0.008(-0.018,0.002)$, standard error $0.005, p=0.132$

In this case, there was an estimated decrease of 0.008 in OR for every additional month of follow-up (Figure 7), although not statistically significant.

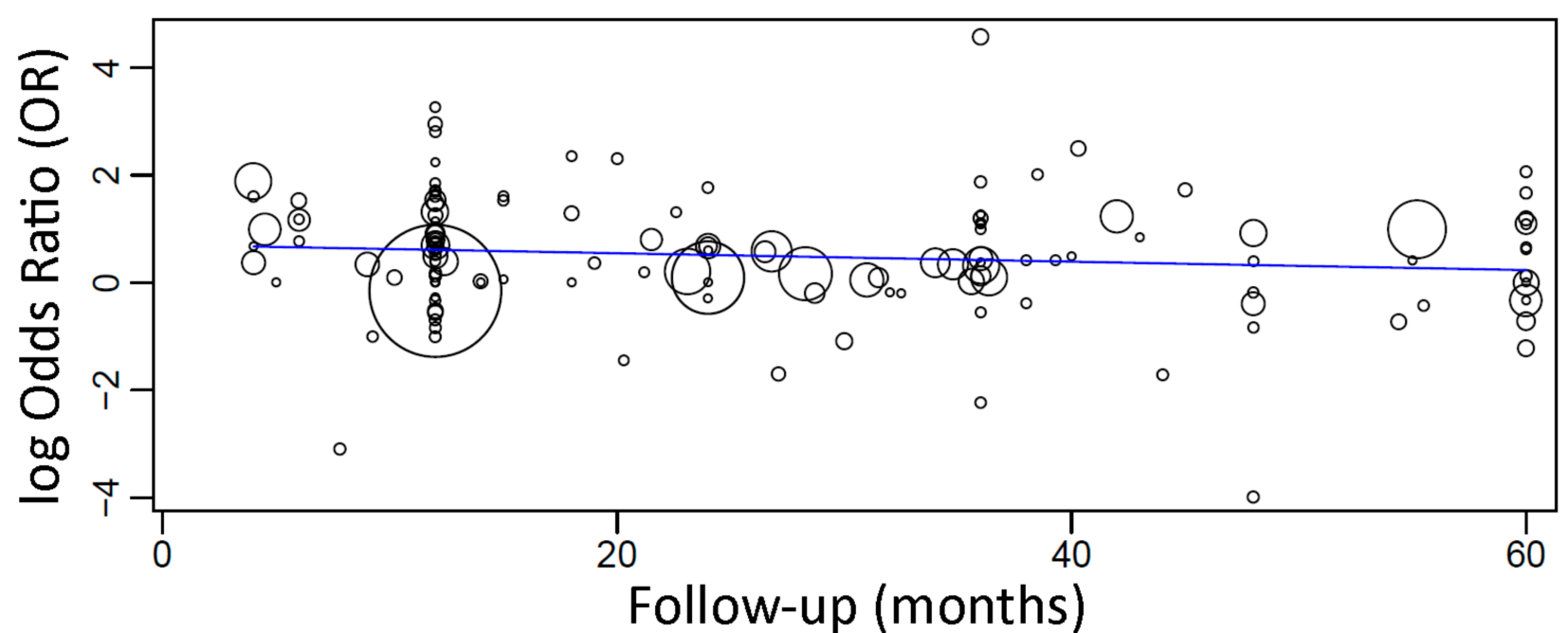

Figure 7. Scatter plot for the meta-regression with the association between the odds ratio (OR) of failure between implants placed in fresh extraction sockets and implants placed in healed sites, and the follow-up time (in months; limited to 60 months). Every circle represents a study, and the size of the circle represents the weight of the study in the analysis.

A meta-regression considering the follow-up period as a covariate in relation to MBL was plotted. The first-degree equation resulted from the linear regression of this meta-regression was

$\mathrm{y}=0.001+0.002 \mathrm{x}$, where:

Intercept $=0.001(-0.123,0.124)$, standard error $0.063, p=0.993$

Follow-up $=0.002(-0.001,0.006)$, standard error $0.002, p=0.230$

A sensitivity analysis of the meta-regression was performed plotting together only the studies with follow-up up until 5 years. The first-degree equation resulted from the linear regression of this sensitivity analysis was

$\mathrm{y}=-0.084+0.006 \mathrm{x}$, where:

Intercept $=-0.084(-0.238,0.071)$, standard error $0.079, p=0.287$

Follow-up $=0.006(0.000,0.012)$, standard error $0.003, p=0.036$

In this case, there was an estimated increase of $0.006 \mathrm{~mm}$ in the mean difference of MBL between groups for every additional month of follow-up (Figure 8), being statistically significant. 


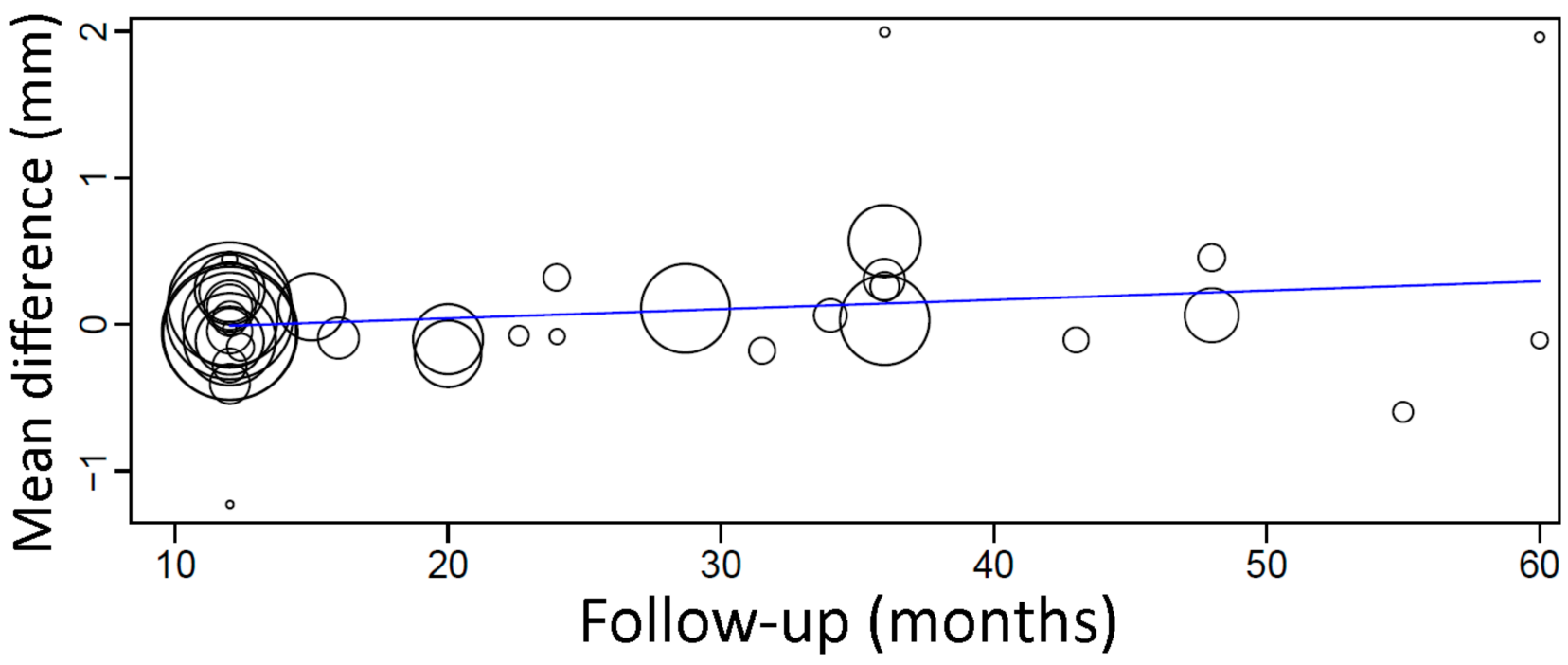

Figure 8. Scatter plot for the meta-regression with the association between follow-up (in months) and MBL mean difference between implants placed in fresh extraction sockets and healed sites. Every circle represents a study, and the size of the circle represents the weight of the study in the analysis.

\subsection{Publication Bias}

The funnel plot did not show a clear asymmetry (Figure 9), indicating possible absence of publication bias.

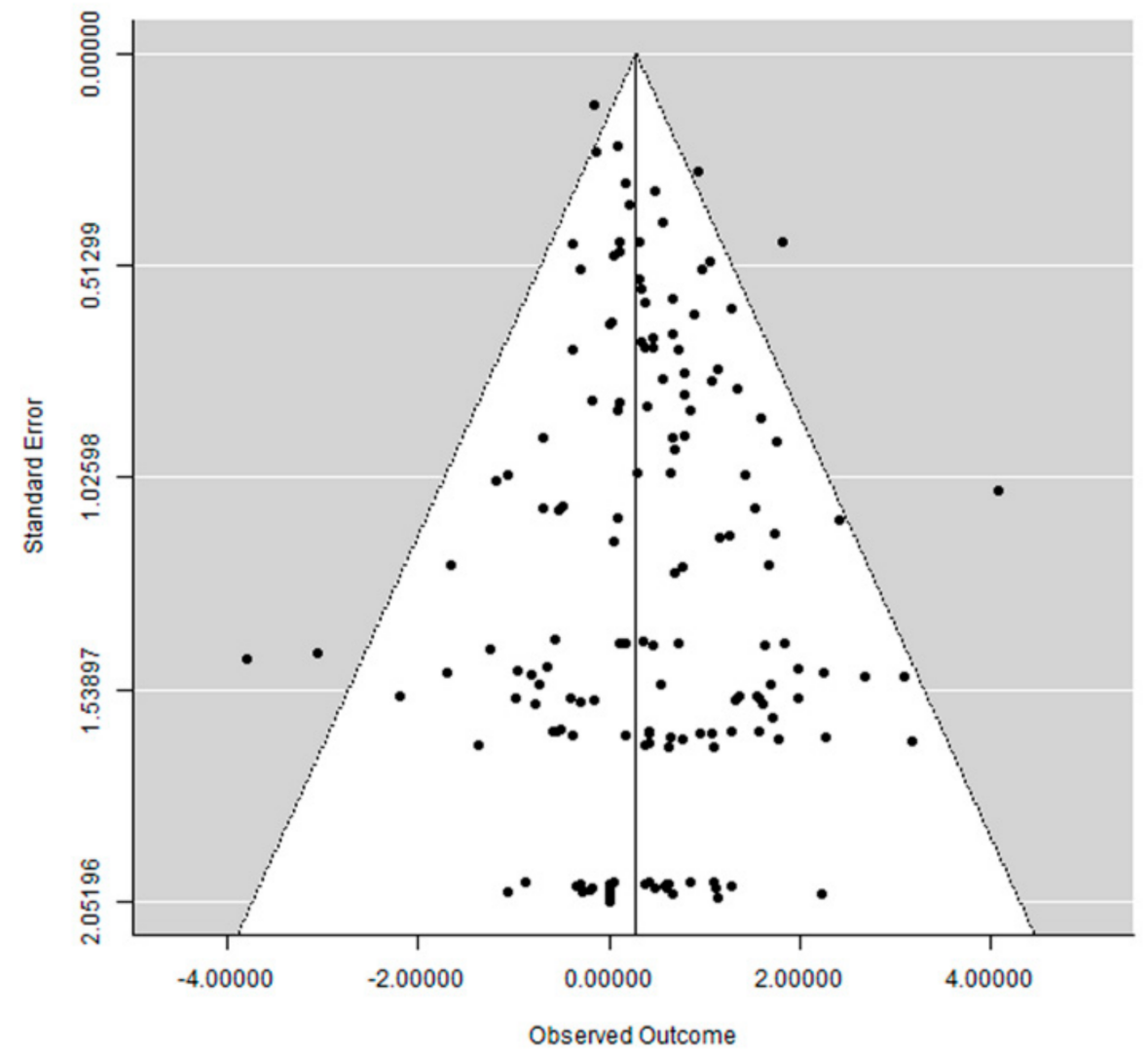

Figure 9. Funnel plot. 


\section{Discussion}

According to the results of the present review, implants placed in fresh extraction sockets presented a statistically significant higher risk of failure than implants placed in healed sites. The null hypothesis regarding failure rates was therefore rejected. However, the hypothesis regarding the MBL was accepted, as the mean difference between the groups was not statistically significant.

There are some possible explanations for the higher implant failure rate when using the fresh extraction socket approach. As the extraction socket is broader than the implant in most of the cases, these implants do not usually engage all the walls of the alveolar bone, only doing so in the apical part of the socket. The primary implant stability can then be compromised [137]. Therefore, it has been recommended that this approach should only be used in the cases where there is enough apical bone to achieve primary stability of the implant, namely, the implant should engage at least $3-5 \mathrm{~mm}$ of apical bone $[177,178]$. Another option would be to install an implant that is wider than the alveolus diameter [5], but this is not feasible in many cases. Tissues affected by periodontitis may make the matters worse, as infrabony defects may result, increasing the gap between the socket walls and the immediately placed implant [179] and making it harder to achieve primary stability [180]. The occurrence of osseous defects may suggest the need of simultaneous guided bone-regeneration procedures [56], which in turn may even be helpful in increasing primary stability of implants placed immediately [181].

Subgroups analyses pooling together either only RCTs or only prospective non-RCT studies resulted in higher effect sizes compared to the analysis including all eligible studies, which included retrospective studies as well. This may be either related or not related to better study designs in relation to retrospective observational studies. The major strength of prospective studies is the accuracy of data collection regarding confounders, exposures, and endpoints [182]. Unfortunately, it was not possible to isolate confounding factors between the two groups regarding different study designs in order to verify their influence on the effect size. Moreover, the majority of the RCT studies included in the presented review were not randomized in relation to the insertion of implants in either fresh extraction sockets or healed sites. Most of these studies were randomized to other factors such as, for example, different loading protocols, number of implants supporting the prosthesis, different implant systems, different implant lengths, and use of prophylactic antibiotics.

Subgroups analyses for the group of studies evaluating implants inserted exclusively by either immediate or delayed loading protocol resulted in statistically significant odds ratio in both cases. However, the risk of failure was $78.5 \%$ and $34.6 \%$ higher for implants placed in sockets in comparison to healed sites when either immediate or delayed loading, respectively, were the exclusive protocol of choice of the studies. Only the fact that an implant is submitted to immediate loading does not lead to a lack of osseointegration and consequently fibrous tissue encapsulation, but the excessive amount of micromotion of the implant during the healing phase [183]. This may have had some influence on the fact that, in relation to implants placed in healed sites, immediately placed but delayedloaded implants had a lower risk of failure than immediately placed and immediately loaded implants.

There was a statistically significant difference in the failure rate between the groups for implants placed in the maxilla, but not in the mandible. This could be related to the fact that sites with poorer bone quality, lack of bone volume, and thin cortical plates, which are more common in the upper jaw, may negatively affect the implant failure rates $[100,184]$. These characteristics of the maxilla may possibly lead to a reduction of the insertion torque of immediate implants in the upper jaw, with a consequent greater difficult-to-attain primary stability $[93,185]$.

The results of the present study suggest that difference in MBL between the groups was not statistically significant. One might expect that the MBL around implants placed in fresh extraction sockets would be higher than in healed sites, as there is resorption of the alveolar bone after the extraction of a tooth [186]. However, there is a tendency of bone 
gain around an implant placed in a socket, as blood clot fills up the space between the implant and the bone walls, resulting in the formation of new bone [187], which increases in a coronal direction and finally apposes around the neck of the implant as healing takes place $[145,188]$. This could help to explain the reason why there was no clear difference in MBL between the approaches.

\section{Limitations of the Present Study}

The results of the present study are not robust due to limitations. First of all, many included studies were retrospective clinical trials, which usually results in the absence of some important information in the publications. Second, many studies have a small sample size and/or a short follow-up period. The latter can result in an underestimation of number of failures. Third, several studies present a low level of specificity, meaning that their aim was not to investigate the difference in the clinical outcomes between the groups being compared in the present review. Last but not least, the studies present many confounding factors that may also affect the clinical outcomes of dental implants, not just the fact that implants were placed in fresh extraction sockets or healed sites. For example, we can cite the influence of implants of different diameters and lengths [189], status of the opposing dental arch, bruxism [190-192], diabetes [193], periodontal status [194], intake of different classes of medicaments by the patients [195-198], irradiation of the head and neck region [199], treatment performed by different professionals [200], different loading protocols [201], other diseases [202-205], type of prosthetic configuration [206-208], and patient's sex [209], among others. Further, individual patients sometimes present with more than one risk factor [210]. The impact of these factors is difficult to estimate if these variables are not identified separately between the different groups.

\section{Conclusions}

- Implants placed in fresh extraction sockets present a 34.9\% higher risk of failure than implants placed in healed sites, when results from all study designs are considered. The risk is $148.7 \%$ and $107.0 \%$ higher for implants placed in fresh extraction sockets when only randomized controlled trials (RCT) and only prospective non-RCT, respectively, were pooled together;

- The difference in implant failure between the groups was statistically significant in the maxilla (higher for fresh extraction socket implants), but not in the mandible;

- The difference in implant failure between the groups was statistically significant for either implants immediately loaded or submitted to delayed load, although the difference was higher when immediate load was applied;

- The mean difference in MBL between the groups was not statistically significant;

- There was an estimated decrease of 0.003 in odds ratio for every additional month of follow-up, although this was not statistically significant.

Supplementary Materials: The following are available online at https:/ / www.mdpi.com/article/10 $.3390 / \mathrm{ma14247903/s1,} \mathrm{Figure} \mathrm{S1:} \mathrm{Forest} \mathrm{plot} \mathrm{for} \mathrm{the} \mathrm{event} \mathrm{'implant} \mathrm{failure',} \mathrm{Figure} \mathrm{S2.} \mathrm{Forest} \mathrm{plot}$ for the event 'implant failure', when only results from RCT studies were pooled together, Figure S3. Forest plot for the event 'implant failure', when only results from prospective non-RCT studies were pooled together, Table S1: Detailed data of the included studies, Table S2: Quality assessment tool, according to the National Institutes of Health (NIH).

Author Contributions: Conceptualization, A.I. and B.R.C.; methodology, B.R.C.; investigation, A.I. and B.R.C.; writing-original draft, A.I. and B.R.C.; formal analysis, B.R.C.; writing-review \& editing, A.I. and B.R.C.; visualization, B.R.C.; supervision, B.R.C. All authors have read and agreed to the published version of the manuscript.

Funding: This research received no external funding.

Institutional Review Board Statement: Not applicable.

Informed Consent Statement: Not applicable. 
Data Availability Statement: The data presented in this study are available within the article and supplementary material.

Acknowledgments: The authors of the present review would like to thank the following authors who provided us additional information about their studies (in alphabetical order of the surname): Enrico Agliardi, Francesco Amato, Balazs Feher, Waleska Caldas Furquim, Reinhard Gruber, Chuh-Teh Lee, Davide Romeo, Markus Schlee, Terry Walton, as well as Paul Rosen, who replied to our e-mail but was not able to provide the missing information.

Conflicts of Interest: The authors declare no conflict of interest.

\section{References}

1. Brånemark, P.I.; Hansson, B.O.; Adell, R.; Breine, U.; Lindström, J.; Hallen, O.; Ohman, A. Osseointegrated implants in the treatment of the edentulous jaw. Experience from a 10-year period. Scand. J. Plast. Reconstr. Surg. Suppl. 1977, 16, 1-132.

2. Schulte, W.; Kleineikenscheidt, H.; Lindner, K.; Schareyka, R. The Tübingen immediate implant in clinical studies. Dtsch. Zahnarztl. Z. 1978, 33, 348-359.

3. Werbitt, M.J.; Goldberg, P.V. The immediate implant: Bone preservation and bone regeneration. Int. J. Periodontics Restor. Dent. 1992, 12, 206-217.

4. Chrcanovic, B.R.; Martins, M.; Wennerberg, A. Immediate Placement of Implants into Infected Sites: A Systematic Review. Clin. Implant Dent. Relat. Res. 2015, 17, e1-e16. [CrossRef] [PubMed]

5. De Rouck, T.; Collys, K.; Cosyn, J. Single-tooth replacement in the anterior maxilla by means of immediate implantation and provisionalization: A review. Int. J. Oral Maxillofac. Implant. 2008, 23, 897-904.

6. Chrcanovic, B.R.; Albrektsson, T.; Wennerberg, A. Dental implants inserted in fresh extraction sockets versus healed sites: A systematic review and meta-analysis. J. Dent. 2015, 43, 16-41. [CrossRef]

7. Page, M.J.; Moher, D.; Bossuyt, P.M.; Boutron, I.; Hoffmann, T.C.; Mulrow, C.D.; Shamseer, L.; Tetzlaff, J.M.; Akl, E.A.; Brennan, S.E.; et al. PRISMA 2020 explanation and elaboration: Updated guidance and exemplars for reporting systematic reviews. BMJ 2021, 372, n160. [CrossRef] [PubMed]

8. US Department of Health \& Human Services. Study Quality Assessment Tools. Available online: https:/ /www.nhlbi.nih.gov / health-topics / study-quality-assessment-tools (accessed on 15 January 2021).

9. Wallace, B.C.; Dahabreh, I.J.; Trikalinos, T.A.; Lau, J.; Trow, P.; Schmid, C.H. Closing the Gap between Methodologists and End-Users: R as a Computational Back-End. J. Stat. Softw. 2012, 49, 1-15. [CrossRef]

10. Wallace, B.C.; Lajeunesse, M.J.; Dietz, G.; Dahabreh, I.J.; Trikalinos, T.A.; Schmid, C.; Gurevitch, J. Open MEE: Intuitive, open-source software for meta-analysis in ecology and evolutionary biology. Methods Ecol. Evol. 2017, 8, 941-947. [CrossRef]

11. Agliardi, E.L.; Pozzi, A.; Stappert, C.F.J.; Benzi, R.; Romeo, D.; Gherlone, E. Immediate Fixed Rehabilitation of the Edentulous Maxilla: A Prospective Clinical and Radiological Study after 3 Years of Loading. Clin. Implant Dent. Relat. Res. 2014, 16, 292-302. [CrossRef]

12. Agnini, A.; Agnini, A.M.; Romeo, D.; Chiesi, M.; Pariente, L.; Stappert, C.F.J. Clinical Investigation on Axial versus Tilted Implants for Immediate Fixed Rehabilitation of Edentulous Arches: Preliminary Results of a Single Cohort Study. Clin. Implant Dent. Relat. Res. 2012, 16, 527-539. [CrossRef]

13. Aguirre-Zorzano, L.; Andres, C.R.; Estefanía-Fresco, R.; Fernandez-Jimenez, A. Immediate temporary restoration of single-tooth implants: Prospective clinical study. Med. Oral Patol. Oral Cir. Bucal 2011, 16, e794-e799. [CrossRef]

14. Aires, I.; Berger, J. Immediate Placement in Extraction Sites Followed by Immediate Loading: A Pilot Study and Case Presentation. Implant Dent. 2002, 11, 87-94. [CrossRef]

15. Alves, C.C.; Correia, A.; Neves, M. Immediate implants and immediate loading in periodontally compromised patients-a 3-year prospective clinical study. Int. J. Periodontics Restor. Dent. 2010, 30, 447-455.

16. Amato, F.; Polara, G.; Spedicato, G.A. Immediate Loading of Fixed Partial Dental Prostheses on Extra-Short and Short Implants in Patients with Severe Atrophy of the Posterior Maxilla or Mandible: An Up-to-4-year Clinical Study. Int. J. Oral Maxillofac. Implant. 2020, 35, 607-615. [CrossRef] [PubMed]

17. Andersson, P.; Degasperi, W.; Verrocchi, D.; Sennerby, L. A Retrospective Study on Immediate Placement of Neoss Implants with Early Loading of Full-Arch Bridges. Clin. Implant Dent. Relat. Res. 2015, 17, 646-657. [CrossRef]

18. Annibali, S.; Bignozzi, I.; Iacovazzi, L.; La Monaca, G.; Cristalli, M.P. Immediate, early, and late implant placement in first-molar sites: A retrospective case series. Int. J. Oral Maxillofac. Implant. 2011, 26, 1108-1122.

19. Arlin, M.L. Analysis Of 435 Screw-Vent Dental Implants Placed in 161 Patients: Software Enhancement of Clinical Evaluation. Implant Dent. 2002, 11, 58-66. [CrossRef] [PubMed]

20. Arora, H.; Ivanovski, S. Immediate and early implant placement in single-tooth gaps in the anterior maxilla: A prospective study on ridge dimensional, clinical, and aesthetic changes. Clin. Oral Implant. Res. 2018, 29, 1143-1154. [CrossRef]

21. Artzi, Z.; Kohen, J.; Carmeli, G.; Karmon, B.; Lor, A.; Ormianer, Z. The efficacy of full-arch immediately restored implantsupported reconstructions in extraction and healed sites: A 36-month retrospective evaluation. Int. J. Oral Maxillofac. Implant. 2010, 25, 329-335. 
22. Atieh, M.A.; Alsabeeha, N.H.M.; Duncan, W.J.; De Silva, R.K.; Cullinan, M.P.; Schwass, D.; Payne, A.G.T. Immediate single implant restorations in mandibular molar extraction sockets: A controlled clinical trial. Clin. Oral Implant. Res. 2012, $24,484-496$. [CrossRef]

23. Bae, M.-S.; Sohn, D.-S.; Ahn, M.-R.; Lee, H.-W.; Jung, H.-S.; Shin, I.-H. Retrospective Multicenter Evaluation of Tapered Implant with a Sandblasted and Acid-Etched Surface at 1 to 4 Years of Function. Implant Dent. 2011, 20, 280-284. [CrossRef]

24. Barbier, L.; Abeloos, J.; De Clercq, C.; Jacobs, R. Peri-implant bone changes following tooth extraction, immediate placement and loading of implants in the edentulous maxilla. Clin. Oral Investig. 2011, 16, 1061-1070. [CrossRef]

25. Bettach, R.; Taschieri, S.; Boukhris, G.; Del Fabbro, M. Implant Survival after Preparation of the Implant Site Using a Single Bur: A Case Series. Clin. Implant Dent. Relat. Res. 2015, 17, 13-21. [CrossRef]

26. Bogaerde, L.V.; Pedretti, G.; Sennerby, L.; Meredith, N. Immediate/Early Function of Neoss Implants Placed in Maxillas and Posterior Mandibles: An 18-Month Prospective Case Series Study. Clin. Implant Dent. Relat. Res. 2008, 12 (Suppl. S1), e83-e94. [CrossRef]

27. Cakarer, S.; Selvi, F.; Can, T.; Kirli, I.; Palancioglu, A.; Keskin, B.; Yaltirik, M.; Keskin, C. Investigation of the Risk Factors Associated with the Survival Rate of Dental Implants. Implant Dent. 2014, 23, 328-333. [CrossRef] [PubMed]

28. Callan, D.P.; Hahn, J.; Hebel, K.; Kwong-Hing, A.; Smiler, D.; Vassos, D.M.; Wohrle, P.; Zosky, J. Retrospective multicenter study of an anodized, tapered, diminishing thread implant: Success rate at exposure. Implant Dent. 2000, 9, 329-336. [CrossRef] [PubMed]

29. Cannata, M.; Grandi, T.; Samarani, R.; Svezia, L.; Grandi, G. A comparison of two implants with conical vs internal hex connections: 1-year post-loading results from a multicentre, randomised controlled trial. Eur. J. Oral Implantol. 2017, 10, 161-168. [PubMed]

30. Cannizzaro, G.; Cavallari, M.; Lazzarini, M.; Purello D’ambrosio, G.; Scialpi, G.; Audino, S.; Velasco-Ortega, E.; Ippolito, D.R.; Esposito, M. Immediate loading of three (fixed-on-3) vs four (fixed-on-4) implants supporting cross-arch fixed prostheses: 1-year results from a multicentre randomised controlled trial. Eur. J. Oral Implantol. 2018, 11, 323-333.

31. Cannizzaro, G.; Felice, P.; Buti, J.; Leone, M.; Ferri, V.; Esposito, M. Immediate loading of fixed cross-arch prostheses supported by flapless-placed supershort or long implants: 1-year results from a randomised controlled trial. Eur. J. Oral Implantol. 2015, 8, 27-36.

32. Cannizzaro, G.; Felice, P.; Gherlone, E.; Barausse, C.; Ferri, V.; Leone, M.; Trullenque-Eriksson, A.; Esposito, M. Immediate loading of two (fixed-on-2) vs four (fixed-on-4) implants placed with a flapless technique supporting mandibular cross-arch fixed prostheses: 3-year results from a pilot randomised controlled trial. Eur. J. Oral Implantol. 2017, 10, 133-145. [PubMed]

33. Cannizzaro, G.; Felice, P.; Lazzarini, M.; Ferri, V.; Leone, M.; Trullenque-Eriksson, A.; Esposito, M. Immediate loading of two flapless placed mandibular implants supporting cross-arch fixed prostheses: A 5-year follow-up prospective single cohort study. Eur. J. Oral Implantol. 2016, 9 (Suppl. S1), 165-177.

34. Cannizzaro, G.; Felice, P.; Leone, M.; Checchi, V.; Esposito, M. Flapless versus open flap implant surgery in partially edentulous patients subjected to immediate loading: 1-year results from a split-mouth randomised controlled trial. Eur. J. Oral Implantol. 2011, 4, 177-188. [PubMed]

35. Cannizzaro, G.; Felice, P.; Leone, M.; Ferri, V.; Viola, P.; Esposito, M. Immediate versus early loading of 6.5 mm-long flaplessplaced single implants: A 4-year after loading report of a split-mouth randomised controlled trial. Eur. J. Oral Implantol. 2012, 5, 111-121.

36. Cannizzaro, G.; Felice, P.; Loi, I.; Viola, P.; Ferri, V.; Leone, M.; Lazzarini, M.; Trullenque-Eriksson, A.; Esposito, M. Machined versus roughened immediately loaded and finally restored single implants inserted flapless: Preliminary 6-month data from a split- mouth randomised controlled trial. Eur. J. Oral Implantol. 2016, 9 (Suppl. S1), 155-163.

37. Cannizzaro, G.; Felice, P.; Trullenque-Eriksson, A.; Lazzarini, M.; Velasco-Ortega, E.; Esposito, M. Immediate vs early loading of $6.6 \mathrm{~mm}$ flapless-placed single implants: 9 years after-loading report of a split-mouth randomised controlled trial. Eur. J. Oral Implantol. 2018, 11, 163-173.

38. Cannizzaro, G.; Gastaldi, G.; Gherlone, E.; Vinci, R.; Loi, I.; Trullenque-Eriksson, A.; Esposito, M. Two or three machined vs roughened surface dental implants loaded immediately supporting total fixed prostheses: 1-year results from a randomised controlled trial. Eur. J. Oral Implantol. 2017, 10, 279-291.

39. Cannizzaro, G.; Leone, M.; Esposito, M. Immediate versus early loading of two implants placed with a flapless technique supporting mandibular bar-retained overdentures: A single-blinded, randomised controlled clinical trial. Eur. J. Oral Implantol. 2008, 1, 33-43. [PubMed]

40. Cannizzaro, G.; Leone, M.; Ferri, V.; Viola, P.; Gelpi, F.; Federico, G.; Esposito, M. Immediate loading of single implants inserted flapless with medium or high insertion torque: A 6-month follow-up of a split-mouth randomised controlled trial. Eur. J. Oral Implantol. 2012, 5, 333-342.

41. Cannizzaro, G.; Loi, I.; Viola, P.; Ferri, V.; Leone, M.; Trullenque-Eriksson, A.; Esposito, M. Immediate loading of two (fixed-on-2) versus three (fixed-on-3) implants placed flapless supporting cross-arch fixed prostheses: One-year results from a randomised controlled trial. Eur. J. Oral Implantol. 2016, 9 (Suppl. S1), 143-153.

42. Cannizzaro, G.; Torchio, C.; Felice, P.; Leone, M.; Esposito, M. Immediate occlusal versus non-occlusal loading of single zirconia implants. A multicentre pragmatic randomised clinical trial. Eur. J. Oral Implantol. 2010, 3, 111-120. [PubMed]

43. Cannizzaro, G.; Torchio, C.; Leone, M.; Esposito, M. Immediate versus early loading of flapless-placed implants supporting maxillary full-arch prostheses: A randomised controlled clinical trial. Eur. J. Oral Implantol. 2008, 9 (Suppl. S1), 127-139. 
44. Capelli, M.; Esposito, M.; Zuffetti, F.; Galli, F.; Del Fabbro, M.; Testroi, T. A 5-year report from a multicentre randomised clinical trial: Immediate non-occlusal versus early loading of dental implants in partially edentulous patients. Eur. J. Oral Implantol. 2010, 3, 209-219.

45. Carr, A.B.; Arwani, N.; Lohse, C.M.; Gonzalez, R.L.V.; Muller, O.M.; Salinas, T.J. Early Implant Failure Associated with Patient Factors, Surgical Manipulations, and Systemic Conditions. J. Prosthodont. 2018, 28, 623-633. [CrossRef]

46. Cavallaro, J.S. Implant Survival and Radiographic Analysis of Proximal Bone Levels Surrounding a Contemporary Dental Implant. Implant Dent. 2011, 20, 146-156. [CrossRef] [PubMed]

47. Cercadillo-Ibarguren, I.; Sánchez-Torres, A.; Figueiredo, R.; Valmaseda-Castellón, E. Early Complications of Immediate Loading in Edentulous Full-Arch Restorations: A Retrospective Analysis of 88 Cases. Int. J. Oral Maxillofac. Implant. 2017, 32, 1116-1122. [CrossRef] [PubMed]

48. Chaushu, G.; Chaushu, S.; Tzohar, A.; Dayan, D. Immediate loading of single-tooth implants: Immediate versus non-immediate implantation. A clinical report. Int. J. Oral Maxillofac. Implant. 2001, 16, 267-272.

49. Checchi, V.; Felice, P.; Zucchelli, G.; Barausse, C.; Piattelli, M.; Pistilli, R.; Grandi, G.; Esposito, M. Wide diameter immediate post-extractive implants vs delayed placement of normal-diameter implants in preserved sockets in the molar region: 1-year post-loading outcome of a randomised controlled trial. Eur. J. Oral Implantol. 2017, 10, 263-278. [PubMed]

50. Ciabattoni, G.; Acocella, A.; Sacco, R. Immediately restored full arch-fixed prosthesis on implants placed in both healed and fresh extraction sockets after computer-planned flapless guided surgery. A 3-year follow-up study. Clin. Implant Dent. Relat. Res. 2017, 19, 997-1008. [CrossRef]

51. Clementini, M.; Agostinelli, A.; Castelluzzo, W.; Cugnata, F.; Vignoletti, F.; De Sanctis, M. The effect of immediate implant placement on alveolar ridge preservation compared to spontaneous healing after tooth extraction: Radiographic results of a randomized controlled clinical trial. J. Clin. Periodontol. 2019, 46, 776-786. [CrossRef] [PubMed]

52. Cooper, L.F.; Raes, F.; Reside, G.J.; Garriga, J.S.; Tarrida, L.G.; Wiltfang, J.; Kern, M.; De Bruyn, H. Comparison of radiographic and clinical outcomes following immediate provisionalization of single-tooth dental implants placed in healed alveolar ridges and extraction sockets. Int. J. Oral Maxillofac. Implant. 2011, 25, 1222-1232.

53. Cooper, L.; Reside, G.J.; Raes, F.; Garriga, J.S.; Tarrida, L.G.; Wiltfang, J.; Kern, M.; De Bruyn, H. Immediate Provisionalization of Dental Implants Placed in Healed Alveolar Ridges and Extraction Sockets: A 5-year Prospective Evaluation. Int. J. Oral Maxillofac. Implant. 2014, 29, 709-717. [CrossRef] [PubMed]

54. Correia, F.; Gouveia, S.; Felino, A.; Costa, A.; Almeida, R. Survival Rate of Dental Implants in Patients with History of Periodontal Disease: A Retrospective Cohort Study. Int. J. Oral Maxillofac. Implant. 2017, 32, 927-934. [CrossRef]

55. Cosyn, J.; Eghbali, A.; Hanselaer, L.; De Rouck, T.; Wyn, I.; Sabzevar, M.M.; Cleymaet, R.; De Bruyn, H. Four Modalities of Single Implant Treatment in the Anterior Maxilla: A Clinical, Radiographic, and Aesthetic Evaluation. Clin. Implant Dent. Relat. Res. 2012, 15, 517-530. [CrossRef]

56. Cosyn, J.; Vandenbulcke, E.; Browaeys, H.; Van Maele, G.; De Bruyn, H. Factors Associated with Failure of Surface-Modified Implants up to Four Years of Function. Clin. Implant Dent. Relat. Res. 2010, 14, 347-358. [CrossRef] [PubMed]

57. Covani, U.; Orlando, B.; D’Ambrosio, A.; Sabattini, V.B.; Barone, A. Immediate Rehabilitation of Completely Edentulous Jaws With Fixed Prostheses Supported by Implants Placed Into Fresh Extraction Sockets and in Healed Sites. Implant Dent. 2012, 21, 272-279. [CrossRef]

58. Crespi, R.; Cappare', P.; Gastaldi, G.; Gherlone, E. Immediate Occlusal Loading of Full-Arch Rehabilitations: Screw-Retained Versus Cement-Retained Prosthesis. An 8-Year Clinical Evaluation. Int. J. Oral Maxillofac. Implant. 2014, 29, 1406-1411. [CrossRef]

59. Cucchi, A.; Vignudelli, S.E.; Franco, S.S.; Ghensi, P.; Malchiodi, L.; Corinaldesi, G. Evaluation of Crestal Bone Loss Around Straight and Tilted Implants in Patients Rehabilitated by Immediate-Loaded Full-Arch All-on-4 or All-on-6: A Prospective Study. J. Oral Implant. 2019, 45, 434-443. [CrossRef]

60. Davarpanah, M.; Caraman, M.; Szmukler-Moncler, S.; Jakubowicz-Kohen, B.; Alcolforado, G. Preliminary data of a prospective clinical study on the Osseotite NT implant: 18-month follow-up. Int. J. Oral Maxillofac. Implant. 2005, 20, 448-454.

61. De Bruyn, H.; Collaert, B. Early loading of machined-surface Brånemark implants in completely edentulous mandibles: Healed bone versus fresh extraction sites. Clin. Implant Dent. Relat. Res. 2002, 4, 136-142. [CrossRef]

62. De Bruyn, H.; Raes, F.; Cooper, L.F.; Reside, G.; Garriga, J.S.; Tarrida, L.G.; Wiltfang, J.; Kern, M. Three-years clinical outcome of immediate provisionalization of single Osseospeed ${ }^{\mathrm{TM}}$ implants in extraction sockets and healed ridges. Clin. Oral Implant. Res. 2012, 24, 217-223. [CrossRef]

63. De Moraes, E.J.; Genovese, F.R. Comparison Between Immediate and Delayed Laser-Treated Implants Surface with Switching Platform: A Clinical Retrospective Study. J. Oral Implant. 2013, 39, 333-338. [CrossRef] [PubMed]

64. Degasperi, W.; Andersson, P.; Verrocchi, D.; Sennerby, L. One-Year Clinical and Radiographic Results with a Novel Hydrophilic Titanium Dental Implant. Clin. Implant Dent. Relat. Res. 2012, 16, 511-519. [CrossRef]

65. Degidi, M.; Daprile, G.; Piattelli, A. Primary Stability Determination by Means of Insertion Torque and RFA in a Sample of 4135 Implants. Clin. Implant Dent. Relat. Res. 2012, 14, 501-507. [CrossRef] [PubMed]

66. Degidi, M.; Piattelli, A.; Carinci, F. Immediate Loaded Dental Implants: Comparison between fixtures inserted in postextractive and healed bone sites. J. Craniofacial Surg. 2007, 18, 965-971. [CrossRef]

67. Degidi, M.; Piattelli, A.; Gehrke, P.; Felice, P.; Carinci, F. Five-year Outcome of 111 Immediate Nonfunctional Single Restorations. J. Oral Implant. 2006, 32, 277-285. [CrossRef] 
68. Degidi, M.; Piattelli, A.; Iezzi, G.; Carinci, F. Immediately loaded short implants: Analysis of a case series of 133 implants. Quintessence Int. 2007, 38, 193-201.

69. Degidi, M.; Piattelli, A.; Iezzi, G.; Carinci, F. Retrospective study of 200 immediately loaded implants retaining 50 mandibular overdentures. Quintessence Int. 2007, 38, 281-288. [PubMed]

70. Deng, F.; Zhang, H.; Zhang, H.; Shao, H.; He, Q.; Zhang, P. A comparison of clinical outcomes for implants placed in fresh extraction sockets versus healed sites in periodontally compromised patients: A 1-year follow-up report. Int. J. Oral Maxillofac. Implant. 2010, 25, 1036-1040.

71. Dhanrajani, P.J.; Al-Rafee, M.A. Single-Tooth Implant Restorations: A Retrospective Study. Implant Dent. 2005, 14, 125-130. [CrossRef]

72. Di Alberti, L.; Donnini, F.; Di Alberti, C.; Camerino, M.; Sgaramella, N.; Lo Muzio, L. Clinical and radiologic evaluation of 70 immediately loaded single implants in the maxillary esthetic zone: Preliminary results after 1 year of functional loading. Int. J. Oral Maxillofac. Implant. 2012, 27, 181-186.

73. Esposito, M.; Barausse, C.; Pistilli, R.; Jacotti, M.; Grandi, G.; Tuco, L.; Felice, P. Immediate loading of post-extractive versus delayed placed single implants in the anterior maxilla: Outcome of a pragmatic multicenter randomised controlled trial 1-year after loading. Eur. J. Oral Implantol. 2015, 8, 347-358.

74. Esposito, M.; Cannizzaro, G.; Bozzoli, P.; Checchi, L.; Ferri, V.; Landriani, S.; Leone, M.; Todisco, M.; Torchio, C.; Testori, T.; et al. Effectiveness of prophylactic antibiotics at placement of dental implants: A pragmatic multicentre placebo-controlled randomised clinical trial. Eur. J. Oral Implantol. 2010, 3, 135-143. [PubMed]

75. Esposito, M.; Grusovin, M.G.; Pellegrino, G.; Soardi, E.; Felice, P. Safety and effectiveness of maxillary early loaded titanium implants with a novel nanostructured calcium-incorporated surface (Xpeed): 1-year results from a pilot multicenter randomised controlled trial. Eur. J. Oral Implantol. 2012, 5, 241-249. [PubMed]

76. Esposito, M.; Zucchelli, G.; Cannizzaro, G.; Checchi, L.; Barausse, C.; Trullenque-Eriksson, A.; Felice, P. Immediate, immediatedelayed (6 weeks) and delayed (4 months) post-extractive single implants: 1-year post-loading data from a randomised controlled trial. Eur. J. Oral Implantol. 2017, 10, 11-26. [PubMed]

77. Evian, C.I.; Emling, R.; Rosenberg, E.S.; Waasdorp, J.A.; Halpern, W.; Shah, S.; Garcia, M. Retrospective analysis of implant survival and the influence of periodontal disease and immediate placement on long-term results. Int. J. Oral Maxillofac. Implant. 2004, 19, 393-398.

78. Feher, B.; Lettner, S.; Heinze, G.; Karg, F.; Ulm, C.; Gruber, R.; Kuchler, U. An advanced prediction model for postoperative complications and early implant failure. Clin. Oral Implant. Res. 2020, 31, 928-935. [CrossRef]

79. Felice, P.; Barausse, C.; Blasone, R.; Favaretto, G.; Stacchi, C.; Calvo, M.; Marin, C.; Buti, J.; Esposito, M. A comparison of two dental implant systems in partially edentulous patients: 1-year post-loading results from a pragmatic mul-ticentre randomised controlled trial. Eur. J. Oral Implantol. 2014, 7, 397-409. [PubMed]

80. Felice, P.; Checchi, L.; Barausse, C.; Pistilli, R.; Sammartino, G.; Masi, I.; Ippolito, D.R.; Esposito, M. Posterior jaws rehabilitated with partial prostheses supported by $4.0 \times 4.0 \mathrm{~mm}$ or by longer implants: One-year post-loading results from a multicenter randomised controlled trial. Eur. J. Oral Implant. 2016, 9, 35-45.

81. Felice, P.; Pistilli, R.; Barausse, C.; Trullenque-Eriksson, A.; Esposito, M. Immediate non-occlusal loading of immediate postextractive versus delayed placement of single implants in preserved sockets of the anterior maxilla: 1-year post-loading outcome of a randomised controlled trial. Eur. J. Oral Implantol. 2015, 8, 361-372.

82. Felice, P.; Soardi, E.; Piattelli, M.; Pistilli, R.; Jacotti, M.; Esposito, M. Immediate non-occlusal loading of immediate post-extractive versus delayed placement of single implants in preserved sockets of the anterior maxilla: 4-month post-loading results from a pragmatic multicentre randomised controlled trial. Eur. J. Oral Implantol. 2011, 4, 329-344.

83. Gehrke, S.A.; Da Silva Neto, U.T.; Rossetti, P.H.O.; Watinaga, S.E.; Giro, G.; Shibli, J.A. Stability of implants placed in fresh sockets versus healed alveolar sites: Early findings. Clin. Oral Implant. Res. 2015, 27, 577-582. [CrossRef]

84. Gelb, D.; McAllister, B.; Nummikoski, P.; Del Fabbro, M. Clinical and Radiographic Evaluation of Brånemark Implants with an Anodized Surface following Seven-to-Eight Years of Functional Loading. Int. J. Dent. 2013, 2013, 1-8. [CrossRef]

85. Gillot, L.; Cannas, B.; Buti, J.; Noharet, R. A retrospective cohort study of 113 patients rehabilitated with immediately loaded maxillary cross-arch fixed dental prostheses in combination with immediate implant placement. Eur. J. Oral Implantol. 2012, 5 , 71-79. [PubMed]

86. Gillot, L.; Noharet, R.; Buti, J.; Cannas, B. A retrospective cohort study of 105 patients rehabilitated with immediately loaded mandibular cross-arch bridges in combination with immediate implant placement. Eur. J. Oral Implantol. 2011, 4, 247-253.

87. Giordano, F.; Esposito, M. Immediate loading of fixed prostheses in fully edentulous jaws-1-year follow-up from a single-cohort retrospective study. Eur. J. Oral Implantol. 2017, 10, 339-348. [PubMed]

88. Gomez-Roman, G.; Schulte, W.; d'Hoedt, B.; Axman-Krcmar, D. The Frialit-2 implant system: Five-year clinical experience in single-tooth and immediately postextraction applications. Int. J. Oral Maxillofac. Implants 1997, 12, 299-309. [PubMed]

89. Grandi, T.; Guazzi, P.; Samarani, R.; Grandi, G. Immediate provisionalisation of single post-extractive implants versus implants placed in healed sites in the anterior maxilla: 1-year results from a multicentre controlled cohort study. Eur. J. Oral Implantol. 2013, 6, 285-295. 
90. Grandi, T.; Guazzi, P.; Samarani, R.; Tohme, H.; Khoury, S.; Sbricoli, L.; Grandi, G.; Esposito, M. Immediate, early (3 weeks) and conventional loading (4 months) of single implants: Preliminary data at 1 year after loading from a pragmatic multicenter randomised controlled trial. Eur. J. Oral Implantol. 2015, 8, 115-126.

91. Guarnieri, R.; Testarelli, L.; Zuffetti, F.; Bertani, P.; Testori, T. Comparative Results of Single Implants with and without LaserMicrogrooved Collar Placed and Loaded with Different Protocols: A Long-Term (7 to 10 years) Retrospective Multicenter Study. Int. J. Oral Maxillofac. Implant. 2020, 35, 841-849. [CrossRef]

92. Haas, R.; Mensdorff-Pouilly, N.; Mailath, G.; Watzek, G. Survival of 1920 IMZ implants followed for up to 100 months. Int. J. Oral Maxillofac. Implant. 1996, 11, 581-588.

93. Horwitz, J.; Zuabi, O.; Peled, M.; Machtei, E.E. Immediate and delayed restoration of dental implants in periodontally susceptible patients: 1-year results. Int. J. Oral Maxillofac. Implant. 2007, 22, 423-429.

94. Huynh-Ba, G.; Hoders, A.B.; Meister, D.J.; Prihoda, T.J.; Mills, M.P.; Mealey, B.L.; Cochran, D.L. Esthetic, clinical, and radiographic outcomes of two surgical approaches for single implant in the esthetic area: 1-year results of a randomized controlled trial with parallel design. Clin. Oral Implant. Res. 2019, 30, 745-759. [CrossRef]

95. Irinakis, T.; Wiebe, C. Clinical Evaluation of the NobelActive Implant System: A Case Series of 107 Consecutively Placed Implants and a Review of the Implant Features. J. Oral Implant. 2009, 35, 283-288. [CrossRef]

96. Jaffin, R.A.; Kumar, A.; Berman, C.L. Immediate loading of dental implants in the completely edentulous maxilla: A clinical report. Int. J. Oral Maxillofac. Implant. 2004, 19, 721-730.

97. Ji, T.-J.; Kan, J.Y.K.; Rungcharassaeng, K.; Roe, P.; Lozada, J.L. Immediate Loading of Maxillary and Mandibular Implant-Supported Fixed Complete Dentures: A 1- to 10-Year Retrospective Study. J. Oral Implant. 2012, 38, 469-477. [CrossRef]

98. Kim, J.K.; Yoon, H.J. Clinical and radiographic outcomes of immediate and delayed placement of dental implants in molar and premolar regions. Clin. Implant Dent. Relat. Res. 2017, 19, 703-709. [CrossRef]

99. Kohen, J.; Matalon, S.; Block, J.; Ormianer, Z. Effect of implant insertion and loading protocol on long-term stability and crestal bone loss: A comparative study. J. Prosthet. Dent. 2016, 115, 697-702. [CrossRef]

100. Kourtis, S.G.; Sotiriadou, S.; Voliotis, S.; Challas, A. Private Practice Results of Dental Implants. Part I: Survival and Evaluation of Risk Factors-Part II: Surgical and Prosthetic Complications. Implant Dent. 2004, 13, 373-385. [CrossRef]

101. Krennmair, S.; Seemann, R.; Weinländer, M.; Krennmair, G.; Piehslinger, E. Immediately loaded distally cantilevered fixed mandibular prostheses supported by four implants placed in both in fresh extraction and healed sites: 2-year results from a prospective study. Eur. J. Oral Implantol. 2014, 7, 173-184.

102. Lee, C.-T.; Tran, D.; Jeng, M.-D.; Shen, Y.-T. Survival rates of hybrid rough surface implants and their alveolar bone level alterations. J. Periodontol. 2018, 89, 1390-1399. [CrossRef]

103. Lee, H.; Fehmer, V.; Hicklin, S.; Noh, G.; Hong, S.-J.; Sailer, I. Three-Dimensional Evaluation of Peri-implant Soft Tissue When Tapered Implants Are Placed: Pilot Study with Implants Placed Immediately or Early Following Tooth Extraction. Int. J. Oral Maxillofac. Implant. 2020, 35, 1037-1044. [CrossRef]

104. Leonida, A.; Vescovi, P.; Baldoni, M.; Rossi, G.; Lauritano, D. Immediate Loading in Mandible Full-Arch: Pilot Study in Patients With Osteoporosis in Bisphosphonate Therapy. J. Oral Implant. 2012, 38, 85-94. [CrossRef]

105. Lindeboom, J.A.; Tjiook, Y.; Kroon, F.H. Immediate placement of implants in periapical infected sites: A prospective randomized study in 50 patients. Oral Surg. Oral Med. Oral Pathol. Oral Radiol. Endodontol. 2006, 101, 705-710. [CrossRef]

106. Locante, W.M. Single-Tooth Replacements in the Esthetic Zone with an Immediate Function Implant: A Preliminary Report. J. Oral Implant. 2004, 30, 369-375. [CrossRef] [PubMed]

107. Luongo, G.; Lenzi, C.; Raes, F.; Eccellente, T.; Ortolani, M.; Mangano, C. Immediate functional loading of single im-plants: A 1-year interim report of a 5-year prospective multicentre study. Eur. J. Oral Implantol. 2014, 7, 187-199. [PubMed]

108. Malchiodi, L.; Balzani, L.; Cucchi, A.; Ghensi, P.; Nocini, P.F. Primary and Secondary Stability of Implants in Postextraction and Healed Sites: A Randomized Controlled Clinical Trial. Int. J. Oral Maxillofac. Implant. 2016, 31, 1435-1443. [CrossRef] [PubMed]

109. Malchiodi, L.; Ghensi, P.; Cucchi, A.; Corrocher, G. A comparative retrospective study of immediately loaded implants in postextraction sites versus healed sites: Results after 6 to 7 years in the maxilla. Int. J. Oral Maxillofac. Implant. 2011, 26, 373-384.

110. Maló, P.; Friberg, B.; Polizzi, G.; Gualini, F.; Vighagen, T.; Rangert, B. Immediate and Early Function of Brånemark System ${ }^{\circledR}$ Implants Placed in the Esthetic Zone: A 1-Year Prospective Clinical Multicenter Study. Clin. Implant Dent. Relat. Res. 2003, 5 (Suppl. S1), 37-46. [CrossRef]

111. Maló, P.; Rangert, B.; Dvärsäter, L. Immediate function of Brånemark implants in the esthetic zone: A retrospective clinical study with 6 months to 4 years of follow-up. Clin. Implant Dent. Relat. Res. 2000, 2, 138-146. [CrossRef]

112. Maló, P.; Rangert, B.; Nobre, M. “All-on-Four" Immediate-Function Concept with Brånemark System ${ }^{\circledR}$ Implants for Completely Edentulous Mandibles: A Retrospective Clinical Study. Clin. Implant Dent. Relat. Res. 2003, 5 (Suppl. S1), 2-9. [CrossRef] [PubMed]

113. Mangano, F.G.; Mangano, C.; Ricci, M.; Sammons, R.L.; Shibli, J.A.; Piattelli, A. Esthetic Evaluation of Single-Tooth Morse Taper Connection Implants Placed in Fresh Extraction Sockets or Healed Sites. J. Oral Implant. 2013, 39, 172-181. [CrossRef]

114. Mangano, F.; Mastrangelo, P.; Luongo, F.; Blay, A.; Tunchel, S.; Mangano, C. Aesthetic outcome of immediately restored single implants placed in extraction sockets and healed sites of the anterior maxilla: A retrospective study on 103 patients with 3 years of follow-up. Clin. Oral Implant. Res. 2016, 28, 272-282. [CrossRef] [PubMed] 
115. Meizi, E.; Meir, M.; Laster, Z. New-Design Dental Implants: A 1-Year Prospective Clinical Study of 344 Consecutively Placed Implants Comparing Immediate Loading Versus Delayed Loading and Flapless Versus Full-Thickness Flap. Int. J. Oral Maxillofac. Implant. 2014, 29, e14-e21. [CrossRef] [PubMed]

116. Mensdorff-Pouilly, N.; Haas, R.; Mailath, G.; Watzek, G. The immediate implant. A retrospective study comparing the different types of immediate implantation. Int. J. Oral Maxillofac. Implant. 1994, 9, 571-578.

117. Mertens, C.; Steveling, H.G. Early and immediate loading of titanium implants with fluoride-modified surfaces: Results of 5-year prospective study. Clin. Oral Implant. Res. 2011, 22, 1354-1360. [CrossRef] [PubMed]

118. Noelken, R.; Kunkel, M.; Jung, B.A.; Wagner, W. Immediate Nonfunctional Loading of NobelPerfect Implants in the Anterior Dental Arch in Private Practice-5-Year Data. Clin. Implant Dent. Relat. Res. 2012, 16, 21-31. [CrossRef] [PubMed]

119. Norton, M.R. A short-term clinical evaluation of immediately restored maxillary TiOblast single-tooth implants. Int. J. Oral Maxillofac. Implant. 2004, 19, 274-281.

120. Norton, M.R. The Influence of Low Insertion Torque on Primary Stability, Implant Survival, and Maintenance of Marginal Bone Levels: A Closed-Cohort Prospective Study. Int. J. Oral Maxillofac. Implant. 2017, 32, 849-857. [CrossRef]

121. Oliva, J.; Oliva, X.; Oliva, J.D. All-on-three delayed implant loading concept for the completely edentulous maxilla and mandible: A retrospective 5-year follow-up study. Int. J. Oral Maxillofac. Implant. 2012, 27, 1584-1592.

122. Ormianer, Z.; Palti, A. Retrospective Clinical Evaluation of Tapered Screw-Vent Implants: Results After up to Eight Years of Clinical Function. J. Oral Implant. 2008, 34, 150-160. [CrossRef]

123. Ormianer, Z.; Piek, D.; Livne, S.; Lavi, D.; Zafrir, G.; Palti, A.; Harel, N. Retrospective Clinical Evaluation of Tapered Implants: 10-year follow-up of delayed and immediate placement of maxillary implants. Implant Dent. 2012, 21, 350-356. [CrossRef]

124. Oxby, G.; Oxby, F.; Oxby, J.; Saltvik, T.; Nilsson, P. Early Loading of Fluoridated Implants Placed in Fresh Extraction Sockets and Healed Bone: A 3- to 5-Year Clinical and Radiographic Follow-Up Study of 39 Consecutive Patients. Clin. Implant Dent. Relat. Res. 2014, 17, 898-907. [CrossRef] [PubMed]

125. Palattella, P.; Torsello, F.; Cordaro, L. Two-year prospective clinical comparison of immediate replacement vs. immediate restoration of single tooth in the esthetic zone. Clin. Oral Implant. Res. 2008, 19, 1148-1153. [CrossRef]

126. Pellicer-Chover, H.; Penarrocha-Oltra, D.; Bagan, L.; Fichy-Fernandez, A.; Canullo, L.; Penarrocha-Diago, M. Single-blind randomized clinical trial to evaluate clinical and radiological outcomes after one year of immediate versus delayed implant placement supporting full-arch prostheses. Med. Oral Patol. Oral Cir. Bucal 2014, 19, e295-e301. [CrossRef] [PubMed]

127. Penarrocha-Diago, M.; Carrillo-Garcîa, C.; Boronat-Lopez, A.; García-Mira, B. Comparative study of wide-diameter implants placed after dental extraction and implants positioned in mature bone for molar replacement. Int. J. Oral Maxillofac. Implant. 2008, 23, 497-501.

128. Penarrocha-Diago, M.; Demarchi, C.L.; Maestre-Ferrín, L.; Carrillo, C.; Penarrocha-Oltra, D.; Penarrocha-Diago, M. A retrospective comparison of 1022 implants: Immediate versus nonimmediate. Int. J. Oral Maxillofac. Implant. 2012, 27, 421-427.

129. Peñarrocha-Diago, M.A.; Maestre-Ferrín, L.; Demarchi, C.L.; Peñarrocha-Oltra, D.; Peñarrocha-Diago, M. Immediate Versus Nonimmediate Placement of Implants for Full-Arch Fixed Restorations: A Preliminary Study. J. Oral Maxillofac. Surg. 2011, 69, 154-159. [CrossRef] [PubMed]

130. Peñarrocha-Oltra, D.; Covani, U.; Aparicio, A.; Ata-Ali, J.; Penarrocha-Diago, M.; Peñarrocha-Diago, M. Immediate versus conventional loading for the maxilla with implants placed into fresh and healed extraction sites to support a full-arch fixed prosthesis: Nonrandomized controlled clinical study. Int. J. Oral Maxillofac. Implant. 2013, 28, 1116-1124. [CrossRef]

131. Penarrocha-Oltra, D.; Demarchi, C.L.; Maestre-Ferrín, L.; Penarrocha-Diago, M.; Penarrocha-Diago, M. Comparison of immediate and delayed implants in the maxillary molar region: A retrospective study of 123 implants. Int. J. Oral Maxillofac. Implant. 2012, 27, 604-610.

132. Perry, J.; Lenchewski, E. Clinical performance and 5-year retrospective evaluation of Frialit-2 implants. Int. J. Oral Maxillofac. Implant. 2004, 19, 887-891.

133. Pettersson, P.; Sennerby, L. A 5-Year Retrospective Study on Replace Select Tapered Dental Implants. Clin. Implant Dent. Relat. Res. 2015, 17, 286-295. [CrossRef]

134. Piek, D.; Livne, S.; Harel, N.; Lerner, H.; Palti, A.; Ormianer, Z. One-Year Survival Rate Outcomes of Innovative Dental Implants: A prospective clinical study. Implant Dent. 2013, 22, 572-577. [CrossRef] [PubMed]

135. Pieri, F.; Aldini, N.N.; Fini, M.; Corinaldesi, G. Immediate Occlusal Loading of Immediately Placed Implants Supporting Fixed Restorations in Completely Edentulous Arches: A 1-Year Prospective Pilot Study. J. Periodontol. 2009, 80, 411-421. [CrossRef]

136. Polizzi, G.; Cantoni, T. Five-Year Follow-Up of Immediate Fixed Restorations of Maxillary Implants Inserted in Both Fresh Extraction and Healed Sites Using the NobelGuide ${ }^{\mathrm{TM}}$ System. Clin. Implant Dent. Relat. Res. 2015, 17, 221-233. [CrossRef]

137. Polizzi, G.; Grunder, U.; Goené, R.; Hatano, N.; Henry, P.; Jackson, W.J.; Kawamura, K.; Renouard, F.; Rosenberg, R.; Triplett, G.; et al. Immediate and delayed implant placement into extraction sockets: A 5-year report. Clin. Implant Dent. Relat. Res. 2000, 2, 93-99. [CrossRef] [PubMed]

138. Pozzi, A.; Mura, P. Clinical and radiologic experience with moderately rough oxidized titanium implants: Up to 10 years of retrospective follow-up. Int. J. Oral Maxillofac. Implant. 2014, 29, 152-161. [CrossRef] [PubMed]

139. Pozzi, A.; Mura, P. Immediate Loading of Conical Connection Implants: Up-to-2-Year Retrospective Clinical and Radiologic Study. Int. J. Oral Maxillofac. Implant. 2016, 31, 142-152. [CrossRef] [PubMed] 
140. Pozzi, A.; Tallarico, M.; Marchetti, M.; Scarfò, B.; Esposito, M. Computer-guided versus free-hand placement of immediately loaded dental implants: 1-year post-loading results of a multicentre randomised controlled trial. Eur. J. Oral Implantol. 2014, 7, 229-242.

141. Pozzi, A.; Tallarico, M.; Moy, P.K. Immediate loading with a novel implant featured by variable-threaded geometry, internal conical connection and platform shifting: Three-year results from a prospective cohort study. Eur. J. Oral Implantol. 2015, 8, 51-63

142. Prati, C.; Zamparini, F.; Canullo, L.; Pirani, C.; Botticelli, D.; Gandolfi, M.G. Factors Affecting Soft and Hard Tissues Around Two-Piece Transmucosal Implants: A 3-Year Prospective Cohort Study. Int. J. Oral Maxillofac. Implant. 2020, 35, 1022-1036. [CrossRef]

143. Prati, C.; Zamparini, F.; Pirani, C.; Montebugnoli, L.; Canullo, L.; Gandolfi, M.G. A Multilevel Analysis of Platform-Switching Flapless Implants Placed at Tissue Level: 4-year Prospective Cohort Study. Int. J. Oral Maxillofac. Implant. 2020, 35, 330-341. [CrossRef]

144. Raes, F.; Cooper, L.F.; Tarrida, L.G.; Vandromme, H.; De Bruyn, H. A case-control study assessing oral-health-related quality of life after immediately loaded single implants in healed alveolar ridges or extraction sockets. Clin. Oral Implant. Res. 2011, 23, 602-608. [CrossRef] [PubMed]

145. Raes, F.; Cosyn, J.; De Bruyn, H. Clinical, Aesthetic, and Patient-Related Outcome of Immediately Loaded Single Implants in the Anterior Maxilla: A Prospective Study in Extraction Sockets, Healed Ridges, and Grafted Sites. Clin. Implant Dent. Relat. Res. 2012, 15, 819-835. [CrossRef]

146. Raes, S.; Eghbali, A.; Chappuis, V.; Raes, F.; De Bruyn, H.; Cosyn, J. A long-term prospective cohort study on immediately restored single tooth implants inserted in extraction sockets and healed ridges: CBCT analyses, soft tissue alterations, aesthetic ratings, and patient-reported outcomes. Clin. Implant Dent. Relat. Res. 2018, 20, 522-530. [CrossRef] [PubMed]

147. Raes, S.; Raes, F.; Cooper, L.; Giner-Tarrida, L.; Vervaeke, S.; Cosyn, J.; De Bruyn, H. Oral health-related quality of life changes after placement of immediately loaded single implants in healed alveolar ridges or extraction sockets: A 5-year prospective follow-up study. Clin. Oral Implant. Res. 2017, 28, 662-667. [CrossRef] [PubMed]

148. Ribeiro, F.S.; Pontes, A.E.F.; Marcantonio, E.; Piattelli, A.; Neto, R.J.B.; Marcantonio, E., Jr. Success Rate of Immediate Nonfunctional Loaded Single-Tooth Implants: Immediate Versus Delayed Implantation. Implant Dent. 2008, 17, 109-117. [CrossRef]

149. Rodrigo, D.; Martin, C.; Sanz, M. Biological complications and peri-implant clinical and radiographic changes at immediately placed dental implants. A prospective 5-year cohort study. Clin. Oral Implant. Res. 2011, 23, 1224-1231. [CrossRef]

150. Romanos, G.E.; Gupta, B.; Gaertner, K.; Nentwig, G.-H. Distal cantilever in full-arch prostheses and immediate loading: A retrospective clinical study. Int. J. Oral Maxillofac. Implant. 2014, 29, 427-431. [CrossRef]

151. Romanos, G.E.; May, S.; May, D. Immediate loading of tooth-implant-supported telescopic mandibular prostheses. Int. J. Oral Maxillofac. Implant. 2012, 27, 1534-1540.

152. Romanos, G.E.; May, S.; May, D. Implant-Supporting Telescopic Maxillary Prostheses and Immediate Loading. Clin. Implant Dent. Relat. Res. 2014, 16, 412-418. [CrossRef]

153. Saridakis, S.K.; Wagner, W.; Noelken, R. Retrospective cohort study of a tapered implant with high primary stability in patients with local and systemic risk factors-7-year data. Int. J. Implant Dent. 2018, 4, 41. [CrossRef] [PubMed]

154. Sato, J.; Watanabe, G.; Ando, M.; Shimoo, Y.; Shizukuda, K.; Kimura, T.; Kobayashi, M. A prospective multicenter study of immediate function of 1-piece implants: A 3-year follow-up report. J. Prosthet. Dent. 2014, 112, 784-791. [CrossRef]

155. Schiegnitz, E.; Al-Nawas, B.; Tegner, A.; Sagheb, K.; Berres, M.; Kämmerer, P.W.; Wagner, W. Clinical and Radiological Long-Term Outcome of a Tapered Implant System with Special Emphasis on the Influence of Augmentation Procedures. Clin. Implant Dent. Relat. Res. 2015, 18, 810-820. [CrossRef] [PubMed]

156. Sennerby, L.; Rocci, A.; Becker, W.; Jonsson, L.; Johansson, L.Å.; Albrektsson, T. Short-term clinical results of Nobel Direct implants: A retrospective multicentre analysis. Clin. Oral Implant. Res. 2008, 19, 219-226. [CrossRef]

157. Siciliano, V.I.; Salvi, G.E.; Matarasso, S.; Cafiero, C.; Blasi, A.; Lang, N.P. Soft tissues healing at immediate transmucosal implants placed into molar extraction sites with buccal self-contained dehiscences. A 12-month controlled clinical trial. Clin. Oral Implant. Res. 2009, 20, 482-488. [CrossRef]

158. Siebers, D.; Gehrke, P.; Schliephake, H. Immediate versus delayed function of dental implants: A 1- to 7-year follow-up study of 222 implants. Int. J. Oral Maxillofac. Implant. 2010, 25, 1195-1202.

159. Swart, L.C.; Dreyer, W.P.; Van Zyl, P.P.; Blignaut, R.J. Early loading of mandibular implants placed immediately after extraction: A 10-year prospective study of eight patients. Int. J. Oral Maxillofac. Implant. 2014, 29, 1388-1396. [CrossRef]

160. Tallarico, M.; Canullo, L.; Pisano, M.; Peñarrocha-Oltra, D.; Peñarrocha-Diago, M.; Meloni, S.M. An up to 7-Year Retrospective Analysis of Biologic and Technical Complication with the All-on-4 Concept. J. Oral Implant. 2016, 42, 265-271. [CrossRef] [PubMed]

161. Tallarico, M.; Xhanari, E.; Pisano, M.; Gatti, F.; Meloni, S.M. Molar replacement with 7 mm-wide diameter implants: To place the implant immediately or to wait 4 months after socket preservation? 1 year after loading results from a randomised controlled trial. Eur. J. Oral Implantol. 2017, 10, 169-178.

162. Testori, T.; Zuffetti, F.; Capelli, M.; Galli, F.; Weinstein, R.L.; Del Fabbro, M. Immediate versus Conventional Loading of Post-Extraction Implants in the Edentulous Jaws. Clin. Implant Dent. Relat. Res. 2014, 16, 926-935. [CrossRef] [PubMed] 
163. Thomé, G.; Caldas, W.; Bernardes, S.R.; Cartelli, C.A.; Gracher, A.H.P.; Trojan, L.C. Implant and prosthesis survival rates of full-arch immediate prostheses supported by implants with and without bicortical anchorage: Up to 2 years of follow-up retrospective study. Clin. Oral Implant. Res. 2021, 32, 37-43. [CrossRef] [PubMed]

164. Thomé, G.; Cartelli, C.A.; Vianna, C.P.; Trojan, L.C. Retrospective Clinical Study of 453 Novel Tapered Implants Placed in All Bone Types: Survival Rate Analysis Up to 2 Years of Follow-Up. Int. J. Oral Maxillofac. Implant. 2020, 35, 757-761. [CrossRef]

165. Tonetti, M.S.; Cortellini, P.; Graziani, F.; Cairo, F.; Lang, N.P.; Abundo, R.; Conforti, G.P.; Marquardt, S.; Rasperini, G.; Silvestri, M.; et al. Immediate versus delayed implant placement after anterior single tooth extraction: The timing randomized controlled clinical trial. J. Clin. Periodontol. 2017, 44, 215-224. [CrossRef]

166. Urdaneta, R.A.; Daher, S.; Leary, J.; Emanuel, K.M.; Chuang, S.-K. The survival of ultrashort locking-taper implants. Int. J. Oral Maxillofac. Implant. 2012, 27, 644-654.

167. Van Kesteren, C.J.; Schoolfield, J.; West, J.; Oates, T. A prospective randomized clinical study of changes in soft tissue position following immediate and delayed implant placement. Int. J. Oral Maxillofac. Implant. 2010, 25, 562-570.

168. Vandeweghe, S.; Ackermann, A.; Bronner, J.; Hattingh, A.; Tschakaloff, A.; De Bruyn, H. A Retrospective, Multicenter Study on a Novo Wide-Body Implant for Posterior Regions. Clin. Implant Dent. Relat. Res. 2009, 14, 281-292. [CrossRef]

169. Walton, T.R. The Up-to-14-Year Survival and Complication Burden of 256 TiUnite Implants Supporting One-Piece Cast Abutment/Metal-Ceramic Implant-Supported Single Crowns. Int. J. Oral Maxillofac. Implant. 2016, 31, 1349-1358. [CrossRef]

170. Watzek, G.; Haider, R.; Mensdorff-Pouilly, N.; Haas, R. Immediate and delayed implantation for complete restoration of the jaw following extraction of all residual teeth: A retrospective study comparing different types of serial immediate implantation. Int. J. Oral Maxillofac. Implant. 1995, 10, 561-567.

171. Wolfinger, G.J.; Balshi, T.J.; Rangert, B. Immediate functional loading of Brånemark system implants in edentulous mandibles: Clinical report of the results of developmental and simplified protocols. Int. J. Oral Maxillofac. Implant. 2003, 18, $250-257$.

172. Zafiropoulos, G.-G.K.; Deli, G.; Bartee, B.K.; Hoffmann, O. Single-Tooth Implant Placement and Loading in Fresh and Regenerated Extraction Sockets. Five-Year Results: A Case Series Using Two Different Implant Designs. J. Periodontol. 2010, 81, 604-615. [CrossRef] [PubMed]

173. Zumstein, T.; Sennerby, L. A 1-Year Clinical and Radiographic Study on Hydrophilic Dental Implants Placed with and without Bone Augmentation Procedures. Clin. Implant Dent. Relat. Res. 2015, 18, 498-506. [CrossRef]

174. Baker, W.L.; White, C.M.; Cappelleri, J.C.; Kluger, J.; Coleman, C.I. Understanding heterogeneity in meta-analysis: The role of meta-regression. Int. J. Clin. Pract. 2009, 63, 1426-1434. [CrossRef]

175. Oxman, A.D.; Guyatt, G.H. A Consumer's Guide to Subgroup Analyses. Ann. Intern. Med. 1992, 116, 78-84. [CrossRef]

176. Ioannidis, J.P.; Patsopoulos, N.A.; Rothstein, H.R. Reasons or excuses for avoiding meta-analysis in forest plots. BMJ 2008, 336, 1413-1415. [CrossRef]

177. Fenner, M.; Vairaktaris, E.; Fischer, K.; Schlegel, K.A.; Neukam, F.W.; Nkenke, E. Influence of residual alveolar bone height on osseointegration of implants in the maxilla: A pilot study. Clin. Oral Implant. Res. 2009, 20, 555-559. [CrossRef]

178. Froum, S.J. Immediate placement of implants into extraction sockets: Rationale, outcomes, technique. Alpha Omegan 2005, 98, 20-35. [PubMed]

179. Carlsson, L.; Rostlund, T.; Albrektsson, B.; Albrektsson, T. Implant fixation improved by close fit. Cylindrical im-plant-bone interface studied in rabbits. Acta Orthop. Scand. 1988, 59, 272-275. [CrossRef] [PubMed]

180. Ivanoff, C.-J.; Sennerby, L.; Lekholm, U. Influence of initial implant mobility on the integration of titanium implants. An experimental study in rabbits. Clin. Oral Implant. Res. 1996, 7, 128-132. [CrossRef]

181. Jun, S.H.; Park, C.-J.; Hwang, S.-H.; Lee, Y.K.; Zhou, C.; Jang, H.-S.; Ryu, J.-J. The influence of bone graft procedures on primary stability and bone change of implants placed in fresh extraction sockets. Maxillofac. Plast. Reconstr. Surg. 2018, 40, 8. [CrossRef] [PubMed]

182. Euser, A.M.; Zoccali, C.; Jager, K.J.; Dekker, F.W. Cohort Studies: Prospective versus Retrospective. Nephron Clin. Pract. 2009, 113, c214-c217. [CrossRef] [PubMed]

183. Wazen, R.M.; Currey, J.A.; Guo, H.; Brunski, J.B.; Helms, J.A.; Nanci, A. Micromotion-induced strain fields influence early stages of repair at bone-implant interfaces. Acta Biomater. 2013, 9, 6663-6674. [CrossRef]

184. Chrcanovic, B.R.; Albrektsson, T.; Wennerberg, A. Bone Quality and Quantity and Dental Implant Failure: A Systematic Review and Meta-analysis. Int. J. Prosthodont. 2017, 30, 219-237. [CrossRef] [PubMed]

185. Sogo, M.; Ikebe, K.; Yang, T.-C.; Wada, M.; Maeda, Y. Assessment of Bone Density in the Posterior Maxilla Based on Hounsfield Units to Enhance the Initial Stability of Implants. Clin. Implant Dent. Relat. Res. 2012, 14, e183-e187. [CrossRef] [PubMed]

186. Schropp, L.; Wenzel, A.; Kostopoulos, L.; Karring, T. Bone healing and soft tissue contour changes following single-tooth extraction: A clinical and radiographic 12-month prospective study. Int. J. Periodontics Restor. Dent. 2003, $23,313-323$.

187. De Sousa Gomes, P.; Daugela, P.; Poskevicius, L.; Mariano, L.; Fernandes, M.H. Molecular and Cellular Aspects of Socket Healing in the Absence and Presence of Graft Materials and Autologous Platelet Concentrates: A Focused Review. J. Oral Maxillofac. Res. 2019, 10, e2. [CrossRef] [PubMed]

188. Covani, U.; Cornelini, R.; Barone, A. Bucco-Lingual Bone Remodeling Around Implants Placed into Immediate Extraction Sockets: A Case Series. J. Periodontol. 2003, 74, 268-273. [CrossRef]

189. Abdel-Halim, M.; Issa, D.; Chrcanovic, B.R. The Impact of Dental Implant Length on Failure Rates: A Systematic Review and Meta-Analysis. Materials 2021, 14, 3972. [CrossRef] 
190. Chrcanovic, B.R.; Albrektsson, T.; Wennerberg, A. Bruxism and Dental Implants. Implant Dent. 2015, 24, 505-516. [CrossRef]

191. Chrcanovic, B.R.; Kisch, J.; Albrektsson, T.; Wennerberg, A. Bruxism and dental implant failures: A multilevel mixed effects parametric survival analysis approach. J. Oral Rehabil. 2016, 43, 813-823. [CrossRef]

192. Chrcanovic, B.R.; Kisch, J.; Albrektsson, T.; Wennerberg, A. Bruxism and dental implant treatment complications: A retrospective comparative study of 98 bruxer patients and a matched group. Clin. Oral Implant. Res. 2016, 28, e1-e9. [CrossRef]

193. Chrcanovic, B.R.; Albrektsson, T.; Wennerberg, A. Diabetes and Oral Implant Failure. J. Dent. Res. 2014, 93, 859-867. [CrossRef] [PubMed]

194. Chrcanovic, B.R.; Albrektsson, T.; Wennerberg, A. Periodontally compromised vs. periodontally healthy patients and dental implants: A systematic review and meta-analysis. J. Dent. 2014, 42, 1509-1527. [CrossRef] [PubMed]

195. Chrcanovic, B.R.; Albrektsson, T.; Wennerberg, A. Bisphosphonates and dental implants: A meta-analysis. Quintessence Int. 2016, 47, 329-342. [CrossRef] [PubMed]

196. Chrcanovic, B.R.; Albrektsson, T.; Wennerberg, A. Dental Implants in Patients Receiving Chemotherapy. Implant Dent. 2016, 25, 261-271. [CrossRef]

197. Chrcanovic, B.R.; Kisch, J.; Albrektsson, T.; Wennerberg, A. Is the intake of selective serotonin reuptake inhibitors associated with an increased risk of dental implant failure? Int. J. Oral Maxillofac. Surg. 2017, 46, 782-788. [CrossRef]

198. Chrcanovic, B.R.; Kisch, J.; Albrektsson, T.; Wennerberg, A. Intake of Proton Pump Inhibitors Is Associated with an Increased Risk of Dental Implant Failure. Int. J. Oral Maxillofac. Implant. 2017, 32, 1097-1102. [CrossRef]

199. Chrcanovic, B.R.; Albrektsson, T.; Wennerberg, A. Dental implants in irradiated versus nonirradiated patients: A meta-analysis. Head Neck 2015, 38, 448-481. [CrossRef]

200. Chrcanovic, B.R.; Kisch, J.; Albrektsson, T.; Wennerberg, A. Impact of Different Surgeons on Dental Implant Failure. Int. J. Prosthodont. 2017, 30, 445-454. [CrossRef]

201. Gjelvold, B.; Kisch, J.; Chrcanovic, B. A Randomized Clinical Trial Comparing Immediate Loading and Delayed Loading of Single-Tooth Implants: 5-Year Results. J. Clin. Med. 2021, 10, 1077. [CrossRef]

202. Chrcanovic, B.R. Dental implants in patients with ectodermal dysplasia: A systematic review. J. Cranio-Maxillofac. Surg. 2018, 46, 1211-1217. [CrossRef]

203. Chrcanovic, B.R.; Gomez, R.S. Dental implants in patients with epidermolysis bullosa: A systematic review. Oral Maxillofac. Surg. 2019, 23, 389-394. [CrossRef] [PubMed]

204. Chrcanovic, B.R.; Kisch, J.; Wennerberg, A. Dental implants in patients with Sjögren's syndrome: A case series and a systematic review. Int. J. Oral Maxillofac. Surg. 2019, 48, 1250-1259. [CrossRef] [PubMed]

205. Chrcanovic, B.R.; Cruz, A.F.; Trindade, R.; Gomez, R.S. Dental Implants in Patients with Oral Lichen Planus: A Systematic Review. Medicina 2020, 56, 53. [CrossRef] [PubMed]

206. Chrcanovic, B.R.; Kisch, J.; Larsson, C. Retrospective evaluation of implant-supported full-arch fixed dental prostheses after a mean follow-up of 10 years. Clin. Oral Implant. Res. 2020, 31, 634-645. [CrossRef] [PubMed]

207. Chrcanovic, B.R.; Kisch, J.; Larsson, C. Analysis of technical complications and risk factors for failure of combined tooth-implantsupported fixed dental prostheses. Clin. Implant Dent. Relat. Res. 2020, 22, 523-532. [CrossRef]

208. Chrcanovic, B.R.; Kisch, J.; Larsson, C. Retrospective clinical evaluation of 2- to 6-unit implant-supported fixed partial dentures: Mean follow-up of 9 years. Clin. Implant Dent. Relat. Res. 2020, 22, 201-212. [CrossRef] [PubMed]

209. Chrcanovic, B.R.; Albrektsson, T.; Wennerberg, A. Dental implants inserted in male versus female patients: A systematic review and meta-analysis. J. Oral Rehabil. 2015, 42, 709-722. [CrossRef]

210. Chrcanovic, B.R.; Kisch, J.; Albrektsson, T.; Wennerberg, A. Analysis of risk factors for cluster behavior of dental implant failures. Clin. Implant Dent. Relat. Res. 2017, 19, 632-642. [CrossRef] 